\title{
Knowing is not enough: exploring the missing link between climate change knowledge and action of German forest owners and managers
}

\author{
Yvonne Hengst-Ehrhart ${ }^{1}$
}

Received: 10 December 2018 / Accepted: 27 August 2019 / Published online: 16 October 2019

(C) INRA and Springer-Verlag France SAS, part of Springer Nature 2019

\begin{abstract}
- Key message Adaptation to climate change is a complex but urgent task in forest management; however, a lack of action is widely reported. This study shows that adaptive action on both stand and business levels is missing in forest management. Beyond the cognitive dimension, affective and conative aspects should be promoted through awareness-raising initiatives specific to different target groups.

- Context Adaptation to climate change is a complex but urgent task in forest management. A lack of action is widely reported combined with a call for awareness-raising and better knowledge transfer to bridge the gap between knowledge and action.

- Aims Based on an understanding of awareness encompassing cognitive, affective, and conative dimensions, the paper aims to clarify (1) what kind of adaptive measures are missing in forest management and (2) if there is a gap in climate change awareness of forest owners and managers hindering adaptive action.

- Methods An online survey among German forest owners and managers was conducted. The theory of planned behavior was selected to examine variables which support the implementation of adaptive measures and to examine different awareness dimensions. Data was analyzed using descriptive statistics and multiple linear regression analysis.

- Results Adaptive measures on stand level were more often implemented than those on business level. All awareness dimensions were influential for the intention to implement adaptive measures. Experience and attitude towards adaptive measures were most important while social norm and perceived behavioral control were influential in some groups.

- Conclusion The potential of adaptive measures on stand level and particularly on business level is not fully exploited. Based on these findings, awareness-raising initiatives and forest consultancy can be adapted to consider the specific perspectives of target groups as a means of promoting the implementation of adaptive measures.
\end{abstract}

Keywords Adaptation · Awareness · Forestry · Theory of planned behavior · Multiple linear regression

\section{Introduction}

"Knowing is not enough; we must apply. Willing is not enough; we must do." This quote from the famous German writer Johann Wolfgang von Goethe expresses the dilemma of forest owners and managers in the context of climate change

This article is part of the topical collection on Risk Analysis

Handling Editor: Rasoul Yousefpour

Yvonne Hengst-Ehrhart

yvonne.hengst-ehrhart@ forst.bwl.de

1 Department of Forestry Economics, Forest Research Institute Baden-Wuerttemberg, Wonnhaldestr. 4, 79100 Freiburg, Germany adaptation. There is a broad consensus among those responsible for forest management that climate change exists and affects their forests (Blennow and Persson 2009; Detten and Faber 2013). Despite this consensus, a lack of adaptive action has been widely documented (IPCC 2012; Pahl et al. 2014; Sousa-Silva et al. 2016, 2018).

Authors attribute the problem to both a (perceived) lack of information about climate change dynamics and impacts (Sousa-Silva et al. 2018; Yousefpour and Hanewinkel 2015) and a lacking sense of urgency (Roeser 2012). As stated by the quote above, knowledge and willingness do not equal action. This is true for many spheres of life, be it proenvironmental behavior (de Leeuw et al. 2015) or ethical buying (Carrington et al. 2010). As with the other examples, climate change adaptation is a complex task and it may be hard to 
evaluate one's own action and whether or not it suffices to make a difference. Therefore, the often quoted uncertainty of forest managers is not only about climate change impacts (Detten and Faber 2013) but also about the efficacy of their own adaptive management decisions. Blennow (2012) states that forest owners who have taken measures to adapt have not perceived a corresponding reduction in climate change risk. In some cases, taking action on climate change even increased risk perception.

Hence, to engage forest owners and managers in adaptation, the key cannot be to simply provide further knowledge but to work on proper knowledge transfer strategies (SousaSilva et al. 2016). Adaptation strategies developed by science and policy need to be actually implemented and accepted by forest managers and owners (Yousefpour and Hanewinkel 2015). This requires adequately addressing the aforementioned uncertainties.

Hulme (2018, p. 334) points out "difficult normative dimensions of the relationship between knowledge, values and action," which have not been sufficiently attended to. He further criticizes the lack of "direct questioning of how knowledge does and should relate to action" (ibid.).

Recent studies in climate change and forest science highlight the need for a more integrative view on climate change awareness. This includes consideration of factors such as people's emotional involvement (Roeser 2012), the importance of experience and willingness to act (Sousa-Silva et al. 2018) as well as group effects among forest owners (Lidskog and Sjödin 2014). These can all been seen as tiles within the mosaic of climate change awareness that bridges the gap between knowledge and action.

\subsection{Approaching climate change awareness}

The term awareness itself is hard to define. According to the Oxford online dictionary it can be described as "knowledge or perception of a fact" (Oxford online dictionary n.d.). The "fact," in many cases, is an issue of public interest or a problem to be solved by those whose awareness is to be raised. Awareness gains its significance through the context in which the term is used and therefore covers more aspects than just the realization or knowledge of an issue. Based on Preisendörfer (1999) and Wendisch (2004), awareness can be defined as an attitude based on three elements: A cognitive element which points to comprehension, a conative element which refers to the willingness to act, and an affective element pointing to the emotional response elicited by the topic, be it fear, outrage or helplessness. At best, all three elements are positively involved since all can be barriers to action (Taddicken and Neverla 2011; Wendisch 2004).

The cognitive dimension of awareness is linked to the classical view of attitude. That is, knowledge and experience influence forest owners' and managers' perceptions of climate change. Blennow et al. (2016) found evidence that education level can be correlated with climate change risk perception. Further studies show that the themes of everyday routines or one's position in an organization shape the way climate change risk is perceived (Detten and Faber 2013). The significance of personal experience is highlighted by many authors, be it experience-based knowledge leading to certain tree species choices (Lidskog and Sjödin 2014) or prior experience with hazards or extreme weather. Evidence of the notion that "seeing is believing" comes from many scientific fields (Weber 2016) and it has been shown that people from regions that have experienced only few extreme weather events in the recent past were less aware of global climate change than those who had frequent experience (Baasch et al. 2012). The idea that experience leads to action is highlighted in many studies on climate change perception (Joireman et al. 2010; Wachinger et al. 2013) but also in forest science specifically (Blennow et al. 2012; Seidl et al. 2016; Sousa-Silva et al. 2016).

This leads to the affective dimension of awareness, since emotions are always part of an experience. The associative system is much faster in making judgements and the concept of "risk as a feeling" (Loewenstein et al. 2001, p. 267) is mostly discussed when emotions amplify risk perception. In the context of climate change, this may differ because the affective system often sends no warning signal while the analytical considerations recognize climate change as a serious concern (Weber 2006). However, emotions are not to be seen as adaptation barriers; rather, they are better understood as a part of practical rationality (Roeser 2012; Slovic et al. 2002). Moreover, intuitions have been shown to be superior to analytical considerations in some cases (Gigerenzer 2008). In the context of forestry, group effects are of particular importance. Lidskog and Sjödin (2014) observed a strong social conformity among forest owners in the aftermath of a storm, when they planted the same tree species against the advice of their consultants. The shared risk was perceived as reduced risk. Furthermore, trust is an important factor to consider. One's own circle of friends and acquaintances is often considered more trustworthy than scientific advice from forestry experts (Grotta et al. 2013).

The interlinkage of climate change adaptation with all areas of life may be one reason for this phenomenon. Climate change is not a behavioral domain as such (Pahl et al. 2014); therefore, the perception of what is thought to be possible, the so-called "adaptive capacity" (Blennow and Persson 2009) or self-efficacy (Blennow et al. 2012), is an individual phenomenon that either promotes or hinders action. This is the conative dimension of awareness. The perceived adaptive capacity is often neglected (Grothmann and Patt 2005) but can be central to actual behavior changes because actual opportunities do not matter when actors believe that their hands are tied (cf. Ajzen et al. 2011). 


\subsection{Theoretical background}

This threefold nature of awareness was first introduced through LaPiere's (1934) research, which played an important role in creating an understanding that general attitude alone cannot predict behavior. The picture was sharpened by Fishbein and Ajzen (1975) who showed the relation between attitude and behavior on comparable levels of specificity and in consideration of intentions as a proxy for behavior. The concept has been further developed as the theory of planned behavior (Ajzen 1991) and is widely used in several spheres of research to understand and predict human behavior (cf. Ajzen and Cote 2008; van Lange et al. 2012), especially in studies researching conservation or pro-environmental behavior (Kaiser et al. 2005; de Leeuw et al. 2015).

The concept explains behavior based on prior intentions (Fig. 1). According to Ajzen (2015), those intentions depend on three types of beliefs or considerations. "Behavioral beliefs" refer to the perceived positive or negative consequences of performing the behavior. Aggregated, they form a negative or positive attitude toward the analyzed behavior. "Normative beliefs" refer to the perceived expectations and behaviors of important referential individuals or groups. They can be understood as social pressure in favor of a certain behavior or social norm. "Control beliefs" are concerned with the perceived ability to perform the behavior. Closely linked to the concept of self-efficacy (Bandura 1977), they form the perceived behavioral control in relation to the behavior in question. The actual behavioral control can be higher or lower but in most cases it is almost impossible to measure. Therefore, perceived behavioral control is typically used as a proxy since it suffices to explain the formation of the behavioral intention (Ajzen 2015). Previous behaviors further add to the model by functioning as "feedback loops" to the aforementioned beliefs by strengthening or weakening these through personal experience (ibid.)

Recent experimental approaches also focus on the theory's suitability for guiding interventions for behavioral change (Steinmetz et al. 2016). The widely documented lack of adaptive action in forestry may be tackled by better understanding what kind of action is missing and if behavioral change can be informed by a theoretical concept of awareness.

Like other applications of the theory (Krüger and Vogt 2007), the study at hand focuses on the core concept of the model, using attitude, social norm and perceived behavioral control to examine intentions toward a certain set of adaptive measures in forestry. Further, behavioral, normative, and control beliefs about climate change in general were used to obtain background information on the broader beliefs of the study participants. The theory of planned behavior covers the cognitive (attitude), affective (social norm), and conative (perceived behavioral control) aspects of awareness and, as such, may not only be suitable for predicting forest owners' and managers' intentions toward a certain adaptive measure but also reveal the gaps in these actors' awareness of climate change adaptation in their forests.

\subsection{Study overview}

Based on the aforementioned dimensions of awareness and the theory of planned behavior, the study at hand is focused on the following two aspects:

First, findings regarding the lack of adaptive action in forestry are mostly based on the self-assessment of study participants who were asked if they have already undertaken measures. Climate change (adaptation) itself is a concept too broad to be fully evaluated, especially in relation to forest owners who are mostly laymen. If action is missing, exactly what action is missing? Broken down into a specific set of adaptive measures, it might be possible to better explore the situation in the field and to understand which specific barriers to adaptation need to be addressed by forest policy.

- Research question 1: What kind of adaptive measures are missing in forest management?

Second, in order to sharpen the picture of climate change awareness in the forestry context, a more holistic understanding of awareness beyond just factual knowledge is needed. The lack of adaptation may be explained better by integrating further aspects like emotion, social conformity and selfefficacy.

- Research question 2: Is there a gap in the climate change awareness of forest owners and managers that can be explained by the theory of planned behavior?

\section{Material and methods}

\subsection{Data collection}

The study is based on an online survey among the two target groups of forest owners and forest managers in Germany, compiled in October 2018. As email contact lists for these groups were not directly available, a snowball sampling was chosen to spread the invitation among target groups. To disseminate the survey, both the national and federal forest owner and manager associations as well as forest administrations were asked to distribute the invitation-including a cover letter explaining the aim of the study and target groups - via their email mailing lists. Most participants were reached through the state forest administration of Baden-Wuerttemberg which forwarded the invitation via its email mailing list. 
Fig. 1 The theory of planned behavior

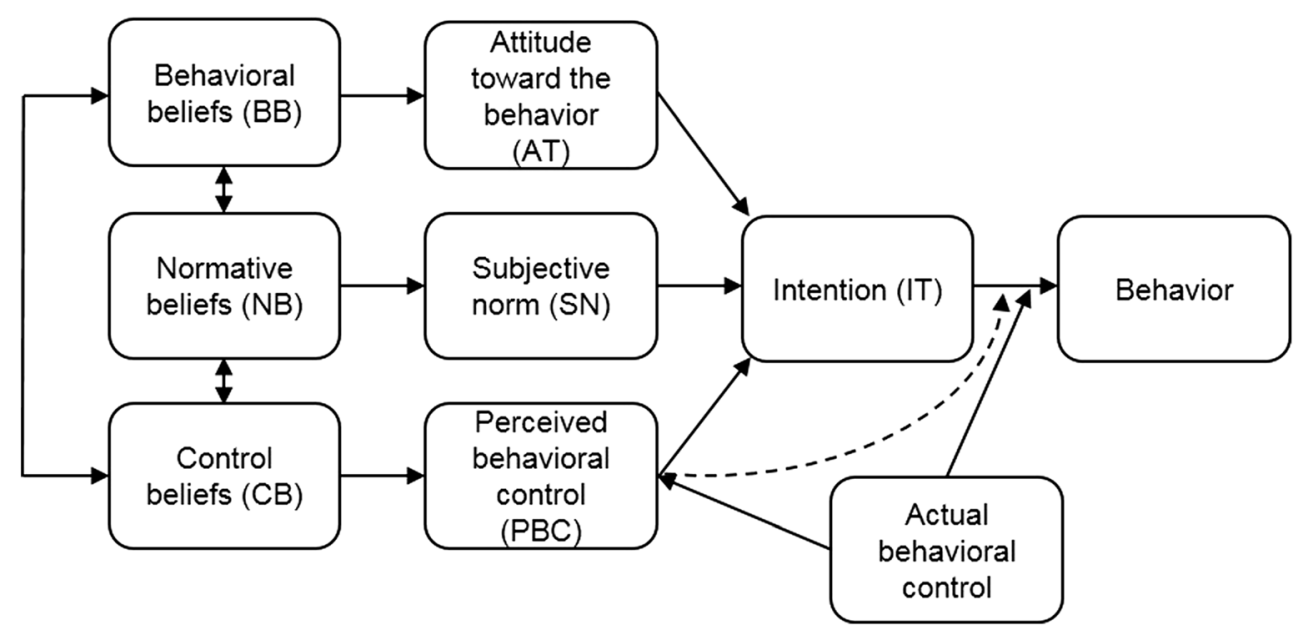

The survey consisted of 23 questions, designed to gather evidence from forest owners and forest managers of different ownership types on their experience with natural hazards (cf. Seidl et al. 2017; Sousa-Silva et al. 2018) and their predictions of future developments. Their beliefs about climate change and its effect on their forests were surveyed. The core of the questionnaire was based on the theory of planned behavior to (i) assess their behavioral, normative, and control beliefs about climate change in general. Further, based on a set of ten adaptive measures (four on stand level, six on business level), determined through literature research (Blennow et al. 2012; Hanewinkel et al. 2011; Morin et al. 2015; Sousa-Silva et al. 2016; Swanston 2016; Yousefpour and Hanewinkel 2015) and their suitability for all polled ownership types, (ii) the attitude towards the behavior or measure (AT), the social norm (SN) and perceived behavioral control (PBC) were covered. A seven-point Likert scale was used to measure risk perception and all questions covering the Theory of Planned Behavior (cf. Ajzen 2002). In addition, basic socio-demographic information on the participants and their managed forests was gathered (for the full questionnaire, see annex, Table 11).

\subsection{Data analysis}

Mean scores and standard deviations were calculated for all scales. Participants could be distinguished into five forest ownership types, which were used for further analysis. These groups are small-scale privately owned forests $(<$ $20 \mathrm{ha}$ ), medium-scale privately owned forests (20-100 ha), large-scale privately owned forests (>100 ha), corporate forests, and state forests.

To add the dimension of hazard experience as a fourth independent variable - in addition to the three theory of planned behavior variables $\mathrm{AT}, \mathrm{SN}$, and $\mathrm{PBC}$ - the responses on hazard experience regarding the nine individual hazards were used to calculate a new variable hazard experience
(HE). This variable is based on the arithmetic mean of the mean scores of all experienced hazards.

An exploratory factor analysis with Varimax rotation was conducted to determine whether the two categories of adaptive measures on stand and on business level occurred in the sample. The findings confirmed the clustering. Accordingly, new variables $\mathrm{IT}_{\mathrm{s}}, \mathrm{AT}_{\mathrm{s}}, \mathrm{SN}_{\mathrm{s}}$, and $\mathrm{PBC}_{\mathrm{s}}$ were calculated based on the arithmetic mean of the means of IT, AT, SN and PBC of the four adaptive measures on stand level ("enrichment with further tree species (mixed forests or on property level)," "cultivation of drought-resistant tree species," "thinning to stabilize forest stands," and "frequent patrols to ensure recognition of potential damages").

Likewise, new variables $\mathrm{IT}_{\mathrm{b}}, \mathrm{AT}_{\mathrm{b}}, \mathrm{SN}_{\mathrm{b}}$, and $\mathrm{PBC}_{\mathrm{b}}$ were calculated based on the arithmetic mean of the means of IT, $\mathrm{AT}, \mathrm{SN}$, and PBC of the six adaptive measures on business level ("shorter rotation periods to secure stand stability," "sufficient road networks to ensure the accessibility of (potentially) damaged areas," "insurance or financial reserves in case of damages (e.g., storm, fire)," "consideration of individual risk factors in operational planning," "adaptation of operational goals to new climatic conditions," and "cooperation and agreements with other forest owners in cases of damage").

As suggested by Ajzen (2015) and Hankins et al. (2000), multiple regression analysis was used for the statistical analysis of the theory of planned behavior model. The effects of the three independent theory of planned behavior variables AT, $\mathrm{SN}$, and $\mathrm{PBC}$ as well as of the additional independent variable $\mathrm{HE}$ on the dependent theory of planned behavior variable IT were measured. Two multiple linear regression analyses were conducted. The first one included the variables of the adaptive measures on stand level $\left(\mathrm{IT}_{\mathrm{s}}, \mathrm{AT}_{\mathrm{s}}, \mathrm{SN}_{\mathrm{s}}, \mathrm{PBC}_{\mathrm{s}}\right)$ as well as $\mathrm{HE}$. The second one included the variables of the adaptive measures on business level ( $\left.\mathrm{IT}_{\mathrm{b}}, \mathrm{AT}_{\mathrm{b}}, \mathrm{SN}_{\mathrm{b}}, \mathrm{PBC}_{\mathrm{b}}\right)$ as well as $\mathrm{HE}$. Subsequently, both multiple linear regression analyses were conducted again, this time individually for the forest ownership types small-scale privately owned forests, medium-scale 
privately owned forests, large-scale privately owned forests, corporate forests, and state forests for adaptive measures on both stand and business levels.

Multiple regression analyses were conducted according to guidelines by Hair (2014) and Hankins et al. (2000). First, assumptions were checked for all twelve multiple regression analyses that were conducted. All assumptions were met, i.e., normal distribution of residuals, independence of residuals, homoscedasticity, absence of multicollinearity, and an acceptable number of outliers. Second, standardized regression coefficients $\beta$, coefficient of determination $R$, adjusted coefficient of determination adj. $R$, partial $F$ value and significances $p$ as well as the percentage of variance explained by each model were reported. Results were considered significant at a level of $p<.05$. All data analyses were executed using the statistical software IBM SPSS 19.

\section{Results}

\subsection{Sample characteristics}

A total of 1189 people participated in the survey, and 972 of these datasets could be used in further analysis. Nearly all participants were from Germany, with $87.3 \%$ residing in the federal state of Baden-Wuerttemberg, 5.6\% in the federal state of Hesse, and $7.0 \%$ in other regions (Fig. 2). Participants were mostly male $(93 \%)$ and aged 18 to $90(M=52.8, S D=10.99)$. Overall, $60.7 \%$ were forest owners, $15.9 \%$ operation managers, and $26.4 \%$ forest rangers. Regarding forestry education, $54.9 \%$ had no forestry-related education, $6.2 \%$ had vocational training, and $38.9 \%$ had an academic education. Furthermore, 46.2\% stated that their forest business is part of a management cooperative. In Table 1, details of the characteristics are shown for the whole sample as well as for the five forest ownership types.

\subsection{Beliefs}

Participants tended to state that climate change will have a strong influence on their forest (climate change belief, $\mathrm{CCB}$ ) $(M=5.58, S D=1.24)$. Moreover, they agreed with the first behavioral belief $(\mathrm{BB})$ that climate change adaptation is an important objective in their forest $\left(\mathrm{BB}_{1}\right)(M=2.02, S D=$ 1.17). To a lesser degree, they also agreed with the second behavioral belief that climate change adaptation is a top priority for them $\left(\mathrm{BB}_{2}\right)(M=1.25, S D=1.48)$. Likewise, they slightly agreed with the first normative belief (NB) that climate change adaptation is an important topic in their professional environment $\left(\mathrm{NB}_{1}\right)(M=1.01, S D=1.57)$. More strongly, they supported the second normative belief statement that adaptation of forest to climate change is an important social task $\left(\mathrm{NB}_{2}\right)(M=1.99, S D=1.33)$. On the contrary, they slightly disagreed with the first control belief $(\mathrm{CB})$ that the present state of science is sufficient for a successful climate change adaptation of their forest business $\left(\mathrm{CB}_{1}\right)(M=-0.79$, $S D=1.63$ ). Moreover, they slightly agreed with the second control belief that it is in their hands as forest owners and managers to successfully adapt their forests to climate change $\left(\mathrm{CB}_{2}\right)(M=0.59, S D=1.69)$. In Table 2, details for the five forest ownership types are shown.

\subsection{Previous experience and future damage risk assessment of hazards}

Previous experience of various hazards among participants differed. On average, forest fire, flood, and landslide/flash flood were experienced never to once. Ice damage, large-scale damages through pathogens (e.g., ash dieback), drought and largescale damages through game to the stand or regeneration were experienced once or seldom. Large-scale damages through insects (e.g., bark beetle) and storm damage were experienced on a range from seldom to often. On average, participants assessed a slightly higher to significantly higher future damage risk for all hazards. Thereby, a clear correlation of experience of hazards and future damage risk assessment could be observed. The more often a hazard was experienced, the higher its future damage risk was assessed (Fig. 3).

\subsection{Adaptive measures}

\subsubsection{Stand level}

Table 3 shows the percentage of participants of each forest ownership type who have already implemented the four adaptive measures on stand level. "Enrichment with further tree species (mixed forests or on property level)," "thinning to stabilize forest stands," and "frequent patrols to ensure recognition of potential damages" have been implemented to a large degree across all forest ownership types, whereas the implementation of "cultivation of drought-resistant tree species" differed across ownership types.

In Table 4, mean scores and standard deviations for the intention to apply each adaptive measure on stand level are presented. AT, $\mathrm{SN}$, and $\mathrm{PBC}$ regarding these measures across all forest ownership types are also listed. Scores for IT and AT were high for all four measures, while values for SN and PBC were lower, particularly SN and PBC for "cultivation of drought-resistant tree species" and SN for "thinning to stabilize forest stands" (for detailed descriptive statistics of adaptive measures on stand level, see annex, Table 12).

Considering the overall mean for adaptive measures on stand level among forest ownership types, all of them had high scores for $\mathrm{IT}_{\mathrm{S}}$ and $\mathrm{AT}_{\mathrm{s}}$. Scores for $\mathrm{SN}_{\mathrm{s}}$ were also positive, but lower overall. $\mathrm{PBC}_{\mathrm{s}}$ differed between forest ownership types, with large-scale privately owned forests scoring highest, closely followed by corporate forests, state forests, and 
Fig. 2 Total number of participants from each federal state contrasted with the forest area of these states. White $=10$ $20 \%$, light grey $=20-30 \%$, grey $=$ $30-40 \%$, dark grey $40-50 \%$ forest coverage

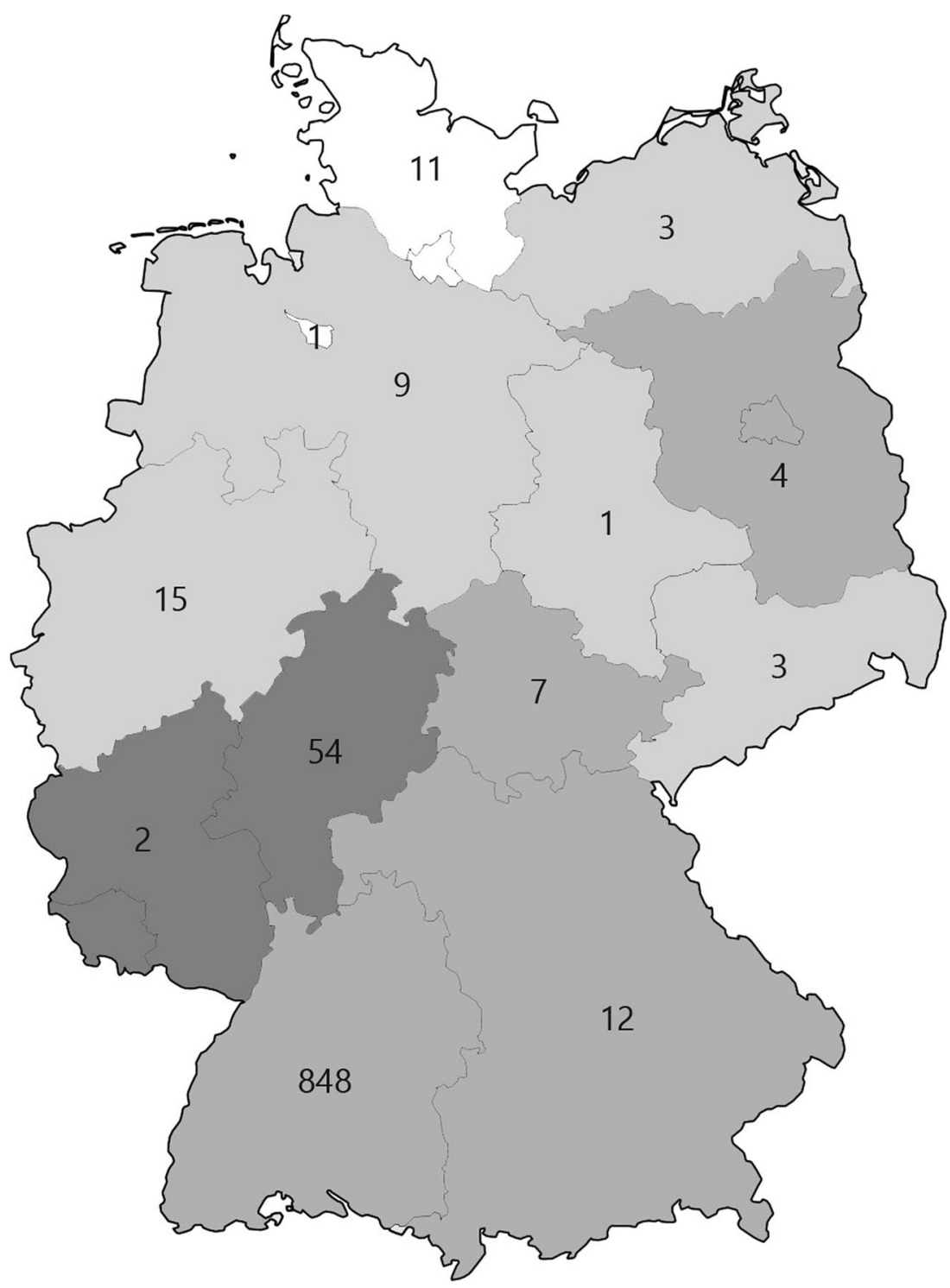

medium-scale privately owned forests, while small-scale privately owned forests had lower scores (Fig. 4).

\subsubsection{Business level}

Table 5 shows the percentage of participants of each forest ownership type who have already implemented the six adaptive measures on business level. In general, numbers are remarkably lower than for adaptive measures on stand level. Most adaptive measures on business level have been implemented much more often in large-scale privately owned forests in particular, but also in corporate forests and state forests, than in small-scale privately owned forests and medium-scale privately owned forests. Moreover, only "sufficient road networks to ensure the accessibility of (potentially) damaged areas" and "adaptation of operational goals to new climatic conditions" have been implemented by more than half of some of the forest ownership types. In addition, "insurance or financial reserves in case of damages (e.g., storm, fire)" scored low among all forest ownership types.

In Table 6, mean scores and standard deviations for the intention to apply each adaptive measure on business level are presented. AT, SN, and PBC regarding these measures among all forest ownership types are also listed. Scores for IT, AT, SN, and PBC were highest for "sufficient road networks to ensure the accessibility of (potentially) damaged areas" and "adaptation of operational goals to new climatic conditions." Values for "shorter rotation periods to secure stand stability," "consideration of individual risk factors in operational planning," and "cooperation and agreements with other forest owners in cases of damage" were near zero. Finally, all four values were negative for "insurance or financial reserves in case of damages (e.g., storm, fire)" (for detailed descriptive statistics of adaptive measures on business level, see annex, Table 13). 
Table 1 Sample characteristics of all participants and for the different forest ownership types small-scale privately owned forests (SPF) $(<20$ ha), mediumscale privately owned forests (MPF) (20-100 ha), large-scale privately owned forests (LPF) (> $100 \mathrm{ha})$, corporate forests $(\mathrm{CF})$, and state forests $(\mathrm{SF})$

\begin{tabular}{|c|c|c|c|c|c|c|}
\hline & \multirow[t]{2}{*}{ Total } & \multicolumn{5}{|c|}{ Forest ownership type } \\
\hline & & SPF & MPF & LPF & $\mathrm{CF}$ & $\mathrm{SF}$ \\
\hline \multicolumn{7}{|l|}{ Gender } \\
\hline Male & $93.0 \%$ & $91.1 \%$ & $94.4 \%$ & $95.7 \%$ & $95.0 \%$ & $94.2 \%$ \\
\hline Female & $7.0 \%$ & $8.9 \%$ & $5.6 \%$ & $4.3 \%$ & $5.0 \%$ & $5.8 \%$ \\
\hline \multicolumn{7}{|l|}{ Age } \\
\hline$<30$ & $2.8 \%$ & $2.9 \%$ & $2.8 \%$ & $0.0 \%$ & $3.4 \%$ & $3.6 \%$ \\
\hline $30-39$ & $9.6 \%$ & $9.9 \%$ & $9.7 \%$ & $10.1 \%$ & $8.4 \%$ & $10.7 \%$ \\
\hline $40-49$ & $20.3 \%$ & $19.8 \%$ & $22.2 \%$ & $20.2 \%$ & $20.2 \%$ & $21.4 \%$ \\
\hline $50-59$ & $40.1 \%$ & $32.5 \%$ & $38.9 \%$ & $37.1 \%$ & $53.7 \%$ & $48.8 \%$ \\
\hline$>59$ & $27.2 \%$ & $34.9 \%$ & $26.4 \%$ & $32.6 \%$ & $14.3 \%$ & $15.5 \%$ \\
\hline \multicolumn{7}{|l|}{ Function (multiple answers possible) } \\
\hline Owner & $60.7 \%$ & $95.0 \%$ & $91.7 \%$ & $52.7 \%$ & $8.3 \%$ & $0.0 \%$ \\
\hline Operations manager & $15.9 \%$ & $11.9 \%$ & $25.0 \%$ & $34.4 \%$ & $15.8 \%$ & $10.3 \%$ \\
\hline Forest ranger & $26.4 \%$ & $1.3 \%$ & $2.8 \%$ & $21.5 \%$ & $66.7 \%$ & $78.2 \%$ \\
\hline Other & $7.8 \%$ & $4.0 \%$ & $8.4 \%$ & $12.9 \%$ & $11.3 \%$ & $12.6 \%$ \\
\hline \multicolumn{7}{|l|}{ Forestry education } \\
\hline No forestry-related education & $54.9 \%$ & $88.2 \%$ & $62.5 \%$ & $28.3 \%$ & $15.2 \%$ & $2.3 \%$ \\
\hline Vocational training & $6.2 \%$ & $4.2 \%$ & $27.8 \%$ & $13.0 \%$ & $3.0 \%$ & $1.2 \%$ \\
\hline Academic education & $38.9 \%$ & $7.6 \%$ & $9.7 \%$ & $58.7 \%$ & $81.8 \%$ & $96.5 \%$ \\
\hline $\begin{array}{l}\text { Forest business part of a management } \\
\text { cooperative }\end{array}$ & $46.2 \%$ & $47.7 \%$ & $83.3 \%$ & $80.6 \%$ & $43.5 \%$ & $74.7 \%$ \\
\hline
\end{tabular}

Overall, scores of adaptive measures on business level were significantly lower than those of adaptive measures on stand level. Depending on the ownership type, $\mathrm{IT}_{\mathrm{b}}$ was negative (small-scale privately owned forests), near zero (medium-scale privately owned forests, state forests), or slightly positive (large-scale privately owned forests, corporate forests). $\mathrm{AT}_{\mathrm{b}}$ was slightly positive for all groups except small-scale privately owned forests, which had a neutral $\mathrm{AT}_{\mathrm{b}}$ value. $\mathrm{SN}_{\mathrm{b}}$ was negative for all groups, while $\mathrm{PBC}_{\mathrm{b}}$ depended on the ownership type, with negative
Table 2 Means $(M)$ and standard deviations $(S D)$ for climate change beliefs $(\mathrm{CCB})$, behavioral beliefs $\left(\mathrm{BB}_{1}, \mathrm{BB}_{2}\right)$, normative beliefs $\left(\mathrm{NB}_{1}\right.$, $\left.\mathrm{NB}_{2}\right)$, and control beliefs $\left(\mathrm{CB}_{1}, \mathrm{CB}_{2}\right)$. Displayed are values for the overall sample as well as for the five forest ownership types small-scale privately owned forests $(\mathrm{SPF})(<20$ ha), medium-scale privately owned forests (MPF) (20-100 ha), large-scale privately owned forests (LPF) (> $100 \mathrm{ha})$, corporate forests (CF), and state forests (SF)

\begin{tabular}{|c|c|c|c|c|c|c|c|c|c|c|c|c|c|c|}
\hline & \multicolumn{2}{|l|}{$\mathrm{CCB}$} & \multicolumn{2}{|l|}{$\mathrm{BB}_{1}$} & \multicolumn{2}{|l|}{$\mathrm{BB}_{2}$} & \multicolumn{2}{|l|}{$\mathrm{NB}_{1}$} & \multicolumn{2}{|l|}{$\mathrm{NB}_{2}$} & \multicolumn{2}{|l|}{$\mathrm{CB}_{1}$} & \multicolumn{2}{|l|}{$\mathrm{CB}_{2}$} \\
\hline & $M^{\mathrm{a}}$ & $S D$ & $M^{\mathrm{b}}$ & $S D$ & $M^{\mathrm{b}}$ & $S D$ & $M^{\mathrm{b}}$ & $S D$ & $M^{\mathrm{b}}$ & $S D$ & $M^{\mathrm{b}}$ & $S D$ & $M^{\mathrm{b}}$ & $S D$ \\
\hline All & 5.58 & 1.24 & 2.02 & 1.17 & 1.25 & 1.48 & 1.01 & 1.57 & 1.99 & 1.33 & -0.79 & 1.63 & 0.59 & 1.69 \\
\hline SPF & 5.42 & 1.32 & 1.96 & 1.23 & 1.14 & 1.56 & 0.86 & 1.61 & 1.88 & 1.39 & -0.69 & 1.65 & 0.73 & 1.72 \\
\hline MPF & 5.66 & 1.15 & 2.07 & 1.03 & 1.50 & 1.43 & 1.01 & 1.47 & 1.89 & 1.53 & -0.71 & 1.50 & 0.53 & 1.71 \\
\hline LPF & 5.62 & 1.28 & 2.02 & 1.14 & 1.33 & 1.49 & 1.37 & 1.47 & 1.98 & 1.60 & -0.81 & 1.73 & 0.47 & 1.81 \\
\hline $\mathrm{CF}$ & 5.80 & 1.08 & 2.10 & 1.05 & 1.35 & 1.29 & 1.21 & 1.48 & 2.21 & 1.01 & -0.95 & 1.54 & 0.32 & 1.57 \\
\hline $\mathrm{SF}$ & 5.78 & 1.16 & 2.06 & 1.27 & 1.28 & 1.51 & 0.85 & 1.66 & 2.15 & 1.22 & -0.89 & 1.70 & 0.74 & 1.67 \\
\hline
\end{tabular}

CCB climate change belief: "Do you think climate change will have an influence on your forest?"; $\mathrm{BB}_{1}$ behavioral belief 1: "I consider climate change adaptation to be an important objective in my forest."; $\mathrm{BB}_{2}$ behavioral belief 2 : "Climate change adaptation is a top priority for me."; $\mathrm{NB}_{1}$ normative belief 1: "Climate change adaptation is an important topic in my professional environment."; $\mathrm{NB}_{2}$ normative belief 2: "I consider the adaptation of forests to climate change an important social task."; $\mathrm{CB}_{1}$ control belief 1: "The present state of science is sufficient for a successful climate change adaptation of my forest business."; $\mathrm{CB}_{2}$ control belief 2: "As forest owners or managers it is in our hands to successfully adapt our forests to climate change"

${ }^{\text {a }}$ Theoretical range $=1-7$

${ }^{\mathrm{b}}$ Theoretical range $=-3-3$ 
Fig. 3 Previous experience and assessment of future damage risk of hazards Theoretical range of previous hazard experience $=0$ 4 Theoretical range of future damage risk assessment $=-3-3$

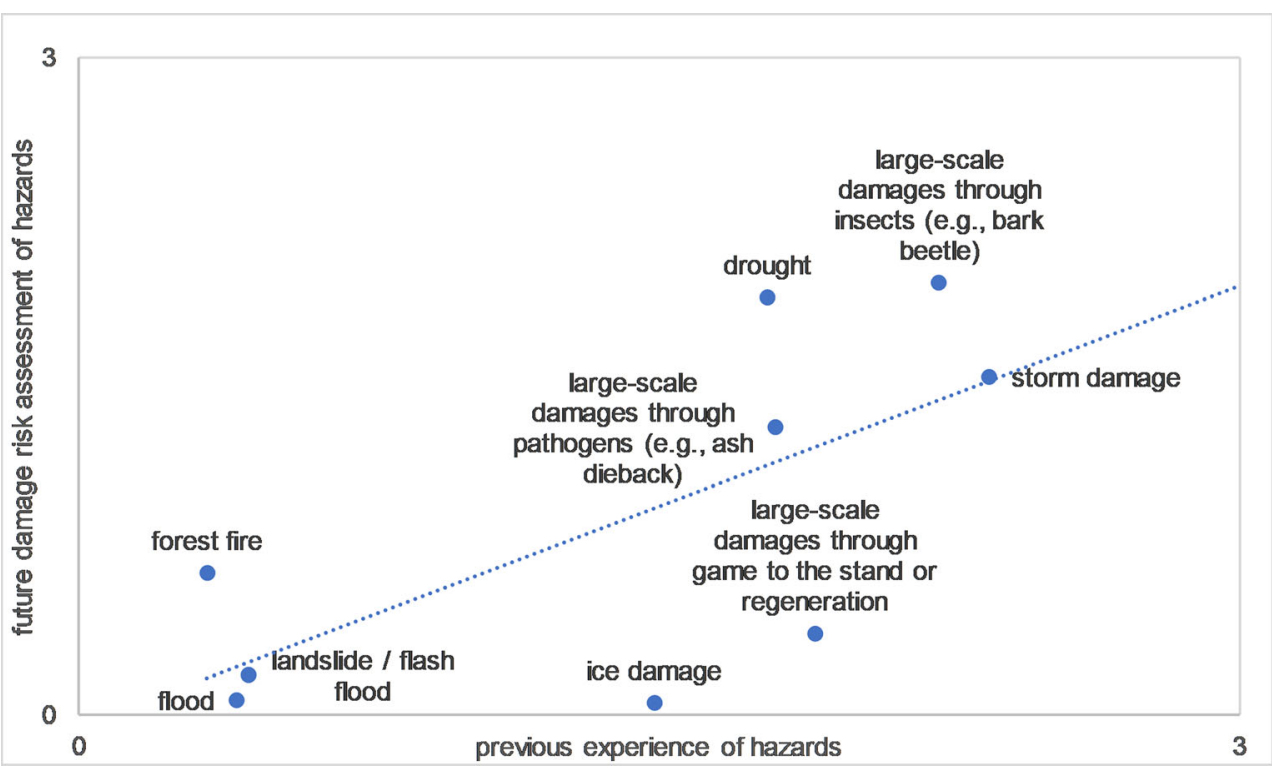

(small-scale privately owned forests), slightly positive (medium-scale privately owned forests, state forests), or more positive values (large-scale privately owned forests, corporate forests) (Fig. 5).

\subsection{Regression analysis}

Table 7 shows the results of the multiple regression analysis for adaptive measures on stand level where $\mathrm{IT}_{\mathrm{s}}$ is the dependent variable. The model uses $\mathrm{AT}_{\mathrm{s}}, \mathrm{SN}_{\mathrm{s}}$, and $\mathrm{PBC}_{\mathrm{s}}$ as well as $\mathrm{HE}$ as independent variables. All variables had a significant positive relationship with $\mathrm{IT}_{\mathrm{s}}$. $\mathrm{AT}_{\mathrm{s}}$ contributed to $\mathrm{IT}_{\mathrm{s}}$ most strongly, followed by $\mathrm{HE}, \mathrm{PBC}_{\mathrm{s}}$, and $\mathrm{SN}_{\mathrm{s}}$. The model explained $45.7 \%$ of the total variance in $\mathrm{IT}_{\mathrm{S}}$.

With respect to the difference between forest ownership types, multiple regression analyses were calculated using the model of intention for each group. Table 8 shows the beta coefficients for the independent variables. For four forest ownership types, $\mathrm{AT}_{\mathrm{s}}$ influenced $\mathrm{IT}_{\mathrm{s}}$ much more strongly than the other variables. Yet, for state forests, $\mathrm{AT}_{\mathrm{s}}$ had a slightly weaker influence, while $\mathrm{SN}_{\mathrm{s}}$ contributed to almost the same degree. For the other ownership types, $\mathrm{SN}_{\mathrm{s}}$ only contributed to $\mathrm{IT}_{\mathrm{s}}$ for corporate forests. $\mathrm{PBC}_{\mathrm{s}}$ influenced $\mathrm{IT}_{\mathrm{s}}$ to some degree for small-scale privately owned forests and large-scale privately owned forests, while HE had a stronger influence for small-scale privately owned forests (and a slight influence for corporate forests). The models explained between $27.0 \%$ and $51.6 \%$ of the total variance in $\mathrm{IT}_{\mathrm{s}}$.

Table 9 shows the results of the multiple regression analysis for adaptive measures on business level where $\mathrm{IT}_{\mathrm{b}}$ is the dependent variable. The model uses $\mathrm{AT}_{\mathrm{b}}, \mathrm{SN}_{\mathrm{b}}$, and $\mathrm{PBC}_{\mathrm{b}}$ as well as $\mathrm{HE}$ as independent variables. All variables had a significant positive influence on $\mathrm{IT}_{\mathrm{b}}$. $\mathrm{AT}_{\mathrm{b}}$ contributed to $\mathrm{IT}_{\mathrm{b}}$ most strongly, followed by $\mathrm{HE}, \mathrm{PBC}_{\mathrm{b}}$, and $\mathrm{SN}_{\mathrm{b}}$. The model explained $51.5 \%$ of the total variance in $\mathrm{IT}_{\mathrm{b}}$.

Again, with respect to the difference between forest ownership types, multiple regression analyses were calculated using the model of intention for each group. Table 10 shows the beta coefficients for the independent variables. For all forest ownership types, $\mathrm{AT}_{\mathrm{b}}$ contributed most to $\mathrm{IT}_{\mathrm{b}}$, with $\mathrm{AT}_{\mathrm{b}}$ having a particularly strong influence for large-scale privately owned forests. $\mathrm{SN}_{\mathrm{b}}$ had a strong influence for state forests and a medium influence for small-scale privately
Table 3 Previous implementation of each adaptive measure on stand level by the five forest ownership types small-scale privately owned forests (SPF) (<20 ha), medium-scale privately owned forests (MPF) (20-
$100 \mathrm{ha}$ ), large-scale privately owned forests (LPF) (> $100 \mathrm{ha}$ ), corporate forests (CF), and state forests (SF)

\begin{tabular}{|c|c|c|c|c|c|}
\hline \multirow[t]{2}{*}{ Adaptive measures on stand level } & \multicolumn{5}{|c|}{ Forest ownership types } \\
\hline & SPF & MPF & LPF & $\mathrm{CF}$ & $\mathrm{SF}$ \\
\hline Species enrichment & $82.6 \%$ & $82.6 \%$ & $90.3 \%$ & $92.5 \%$ & $93.1 \%$ \\
\hline Drought resist. species & $43.7 \%$ & $61.1 \%$ & $72.0 \%$ & $80.4 \%$ & $74.7 \%$ \\
\hline Thinning & $78.5 \%$ & $79.2 \%$ & $82.8 \%$ & $87.1 \%$ & $86.2 \%$ \\
\hline Patrols & $87.9 \%$ & $86.1 \%$ & $86.0 \%$ & $82.5 \%$ & $88.5 \%$ \\
\hline
\end{tabular}


Table 4 Means $(M)$ and standard deviations $(S D)$ for intention (IT), attitude (AT), social norm (SN), and perceived behavioral control (PBC) regarding each adaptive measure on stand level

\begin{tabular}{|c|c|c|c|c|c|c|c|c|}
\hline \multirow[t]{3}{*}{ Adaptive measures on stand level } & \multicolumn{8}{|c|}{ Variables } \\
\hline & \multicolumn{2}{|l|}{ IT } & \multicolumn{2}{|l|}{ AT } & \multicolumn{2}{|l|}{$\mathrm{SN}$} & \multicolumn{2}{|l|}{$\mathrm{PBC}$} \\
\hline & $M^{\mathrm{a}}$ & $S D$ & $M^{\mathrm{a}}$ & $S D$ & $M^{\mathrm{a}}$ & $S D$ & $M^{\mathrm{a}}$ & $S D$ \\
\hline Species enrichment & 1.85 & 1.39 & 2.07 & 1.23 & 1.09 & 1.63 & 1.25 & 1.57 \\
\hline Drought resist. species & 1.46 & 1.59 & 1.95 & 1.24 & 0.76 & 1.72 & 0.76 & 1.72 \\
\hline Thinning & 1.51 & 1.53 & 1.23 & 1.55 & 0.72 & 1.63 & 1.38 & 1.61 \\
\hline Patrols & 1.93 & 1.41 & 1.71 & 1.51 & 1.00 & 1.69 & 1.54 & 1.54 \\
\hline
\end{tabular}

${ }^{\mathrm{a}}$ Theoretical range $=-3-3$ owned forests and corporate forests. $\mathrm{PBC}_{\mathrm{b}}$ had an influence only for small-scale privately owned forests, while HE contributed more strongly to $\mathrm{IT}_{\mathrm{b}}$ for small-scale privately owned forests and to some degree also for corporate forests and state forests. The models explained between $42.6 \%$ and $63.1 \%$ of the total variance of $\mathrm{IT}_{\mathrm{b}}$.

\section{Discussion}

Results show that climate change adaptation is seen as an important issue among all forest ownership types. Participants consider the topic to be important on a societal level but it is less present in their professional environment. The problem of a lack of knowledge about how to successfully adapt forests was identified by all groups, yet, a slight tendency towards an optimistic view that climate change lies in the hands of forest managers can be reported. This adds to the aforementioned problem of a perceived lack of knowledge as one main constraint on adaptation (c.f. Sousa-Silva et al. 2018; Yousefpour and Hanewinkel 2015). Moreover, the importance of experience in relation to risk perception (e.g., Lawrence et al. 2014; Wachinger et al. 2013) has been confirmed. Participants perceived a higher risk of future damage for hazards they had already experienced. Drought and damages through insects had comparatively high values in terms of the perceived future increased risk. Those two hazards occurred in summer 2018 throughout Germany. "Fresh experience" may therefore be the door-opener for

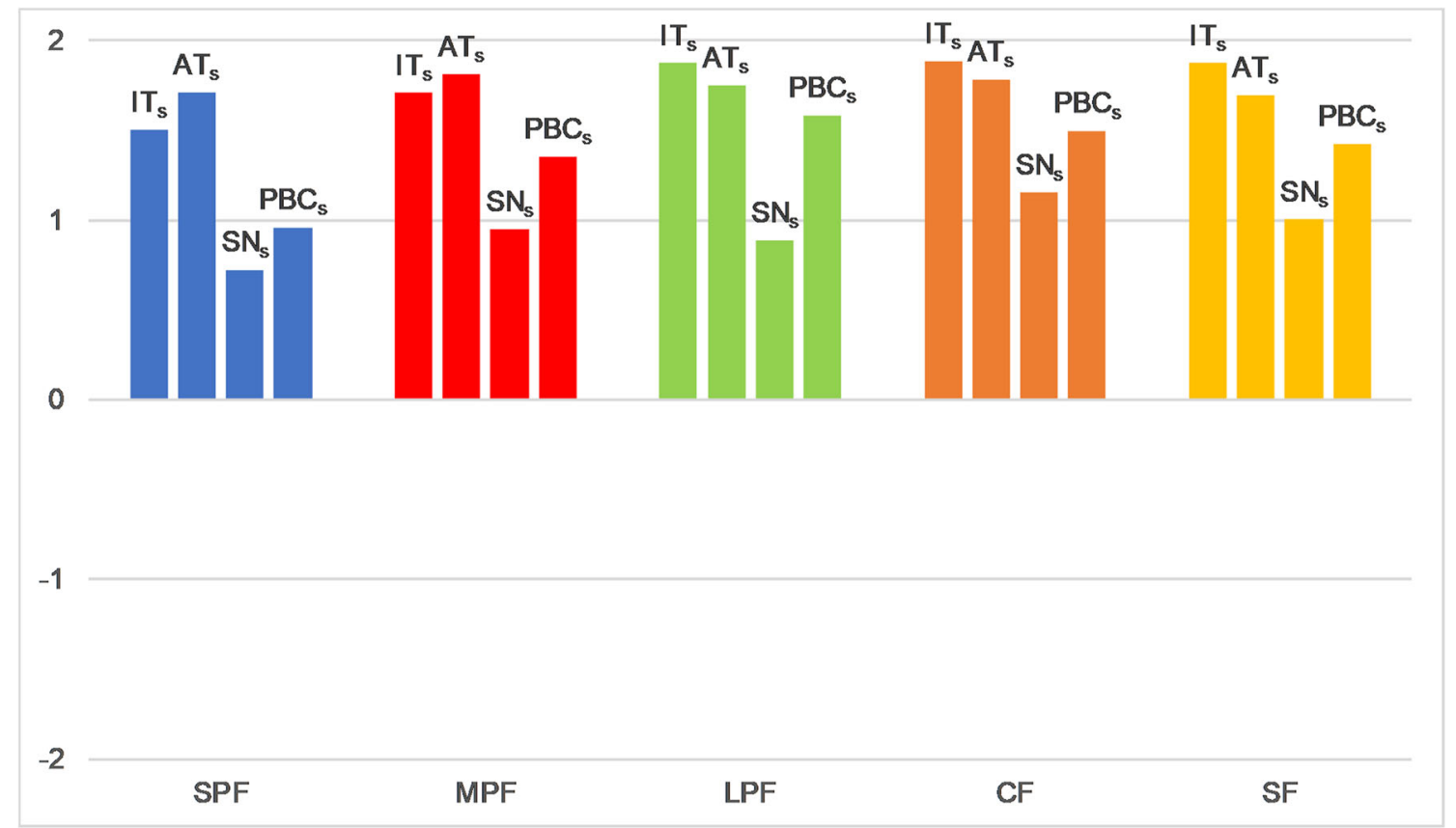

Fig. 4 Graphical comparison of means for intention (IT ), attitude (AT), social norm (SN ) and perceived behavioral control (PBC ) regarding adaptive measures on stand level. Displayed are values for the five forest ownership types small-scale privately owned forests (SPF) $(<20$ ha), medium-scale privately owned forests (MPF) (20-100 ha), largescale privately owned forests (LPF) (> $100 \mathrm{ha}$ ), corporate forests (CF) and state forests $(\mathrm{SF})$ Theoretical range $=-3-3$ 
Table 5 Previous implementation of each adaptive measure on business level by the five forest ownership types small-scale privately owned forests (SPF) $(<20$ ha), medium-scale privately owned forests (MPF) $(20$
100 ha), large-scale privately owned forests (LPF) (> 100 ha), corporate forests $(\mathrm{CF})$, and state forests $(\mathrm{SF})$

\begin{tabular}{|c|c|c|c|c|c|}
\hline \multirow[t]{2}{*}{ Adaptive measures on business level } & \multicolumn{5}{|c|}{ Forest ownership types } \\
\hline & SPF & MPF & LPF & $\mathrm{CF}$ & $\mathrm{SF}$ \\
\hline Shorter rotation & $10.5 \%$ & $19.4 \%$ & $37.6 \%$ & $29.2 \%$ & $34.5 \%$ \\
\hline Accessibility & $34.1 \%$ & $58.3 \%$ & $74.2 \%$ & $59.2 \%$ & $59.8 \%$ \\
\hline Insurance/reserves & $6.1 \%$ & $13.9 \%$ & $24.7 \%$ & $13.8 \%$ & $0.0 \%$ \\
\hline Risk planning & $13.6 \%$ & $20.8 \%$ & $37.6 \%$ & $49.6 \%$ & $37.9 \%$ \\
\hline Adaptation of goals & $27.8 \%$ & $36.1 \%$ & $61.3 \%$ & $51.7 \%$ & $47.1 \%$ \\
\hline Cooperation & $37.0 \%$ & $37.5 \%$ & $33.3 \%$ & $32.5 \%$ & $34.5 \%$ \\
\hline
\end{tabular}

awareness-raising initiatives until other, day-to-day issues that are "simply more salient, compelling and urgent" demand attention again (Pahl et al. 2014, p. 380).

\subsection{What kind of adaptive action is missing?}

According to the results, adaptive measures on stand level are far more widely implemented and accepted by all ownership types than measures based on considerations of the whole business entity. This corresponds to the results of PröbstlHaider et al. (2017) who also reported a tendency of forest owners to think on the tree or stand level instead of recognizing their business as a whole. Interestingly, participants do not view adaptive measures implemented and positively discussed by others in the same way they perceive their own. This may be due to the aforementioned difficulty in evaluating one's own and others actions in light of a complex field like climate change (Blennow et al. 2012). This assessment may also be due to a phenomenon called "unrealistic optimism," leading to a more positive view of one's own situation compared to others (Grothmann and Patt 2005).

Adaptive measures on business level had generally lower values. Compared to measures on stand level, the attitude toward the measure was, on average, in all cases more positive than the intention to implement them. This can be interpreted as an indication of implementation problems, which fits the relation between perceived behavioral control and the noticeable gap between the intention to implement and the attitude towards a measure. Higher investments or efforts might be one reason for some of these results, particularly with regard to insurance, reserves, or risk planning which can require expert knowledge.

Another problem with these kinds of measures is that they do not have a directly visible effect. Many studies have shown that future rewards appear less appealing the more distant they are (Pahl et al. 2014), maybe because they do not address the concept of "risk as a feeling" (Loewenstein et al. 2001, p. 267) in the same way that the more obvious measures do.

However, results suggest that there is some adaptive potential in measures that zoom out to the business level of a property. This can be addressed by forest policy. In light of the growing importance of concepts such as resilience in improving adaptation and flexibility (Detten and Hanewinkel 2017) or robust decision making (Yousefpour et al. 2017), those strategies need to be addressed on a broader level since the complexity of climate change cannot be tackled by simplified solutions (Aldunce et al. 2016).

In this regard, no- or low-regret measures can be promising since they are robust options by design (Dittrich et al. 2016). Watkiss et al. (2015) argue that early no- and low-regret
Table 6 Means $(M)$ and standard deviations $(S D)$ for intention (IT), attitude (AT), social norm (SN), and perceived behavioral control (PBC) regarding each adaptive measure on business level

\begin{tabular}{|c|c|c|c|c|c|c|c|c|}
\hline \multirow[t]{2}{*}{ Adaptive measures on business level } & \multicolumn{8}{|c|}{ Variables } \\
\hline & $\begin{array}{l}\text { IT } \\
M^{\mathrm{a}}\end{array}$ & $S D$ & $\begin{array}{l}\mathrm{AT} \\
M^{\mathrm{a}}\end{array}$ & $S D$ & $\begin{array}{l}\mathrm{SN} \\
M^{\mathfrak{a}}\end{array}$ & $S D$ & $\begin{array}{l}\mathrm{PBC} \\
M^{\mathrm{a}}\end{array}$ & $S D$ \\
\hline Shorter rotation & -0.36 & 1.97 & 0.02 & 1.88 & -0.39 & 1.73 & 0.18 & 1.94 \\
\hline Accessibility & 0.29 & 2.02 & 0.73 & 1.78 & 0.17 & 1.78 & 0.76 & 1.91 \\
\hline Insurance/reserves & -1.74 & 1.71 & -1.13 & 1.86 & -1.63 & 1.58 & -1.28 & 1.91 \\
\hline Risk planning & -0.11 & 2.05 & -0.30 & 1.86 & -0.42 & 1.79 & -0.13 & 1.94 \\
\hline Adaptation of goals & 0.77 & 1.87 & 1.20 & 1.68 & 0.06 & 1.81 & 0.31 & 1.84 \\
\hline Cooperation & 0.15 & 2.09 & 0.35 & 1.95 & -0.31 & 1.90 & -0.03 & 2.01 \\
\hline
\end{tabular}

${ }^{\mathrm{a}}$ Theoretical range $=-3-3$ 
Fig. 5 Graphical comparison of means for intention (IT ), attitude (AT ), social norm (SN) and perceived behavioral control (PBC) regarding adaptive measures on business level. Displayed are values for the five forest ownership types smallscale privately owned forests (SPF) $(<20$ ha), medium-scale privately owned forests (MPF) (20-100 ha), large-scale privately owned forests (LPF) (> 100 ha), corporate forests $(\mathrm{CF})$ and state forests $(\mathrm{SF})$ Theoretical range $=-$ $3-3$
2

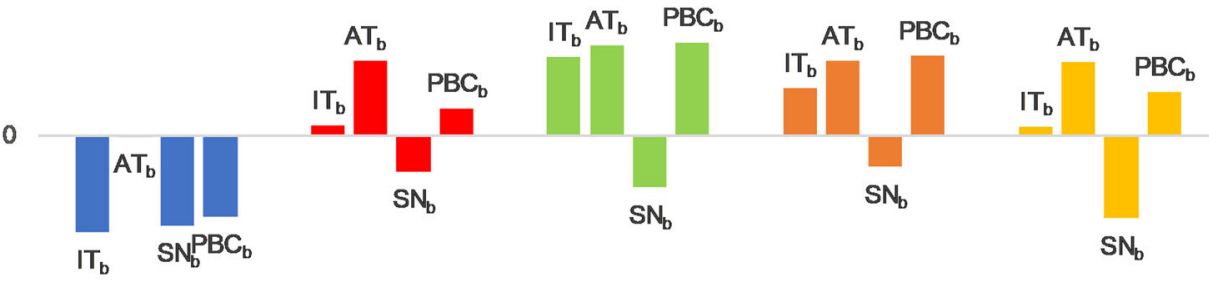

$-1$

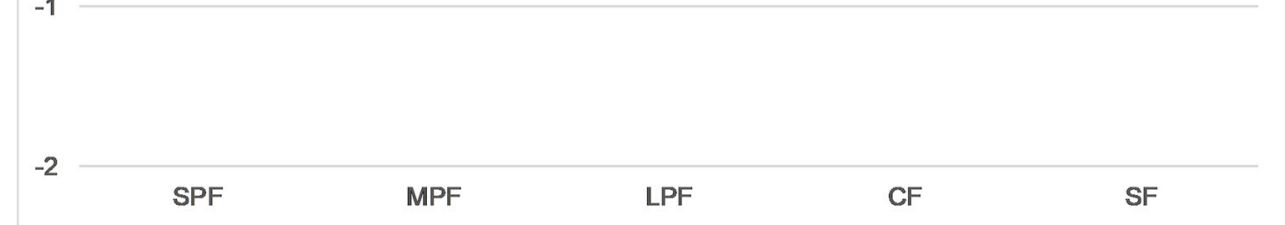

measures should be framed as iterative options to build longterm adaptive capacity. By promoting these measures, adaptive action can be set as a default option to increase the likelihood of further efforts.

Yet, small-scale private forests need to be viewed differently. When property sizes are small, forests do not matter to the owner as much as larger properties and owners do not consider their forests to be small businesses. If so, this issue may be addressed by supporting cooperative initiatives between owners to enhance efficiency. However, economic insignificance may not be the only reason for this perspective. Individual, social, and cultural values among small-scale private forest owners, who represent a large portion of the general society, may also contradict the idea of forests as businesses (Blennow et al. 2019; Feil et al. 2018). Policy instruments and consultation sensitive to such values are strongly

Table 7 Results of multiple regression analysis with the intention to apply adaptive measures on stand level $\left(\mathrm{IT}_{\mathrm{s}}\right)$ as the dependent variable and attitude $\left(\mathrm{AT}_{\mathrm{S}}\right)$, social norm $\left(\mathrm{SN}_{\mathrm{s}}\right)$, and perceived behavioral control $\left(\mathrm{PBC}_{\mathrm{s}}\right)$ regarding these measures as well as hazard experience $(\mathrm{HE})$ as independent variables

\begin{tabular}{llll}
\hline Scales & \multicolumn{3}{l}{$\mathrm{IT}_{\mathrm{s}}$} \\
\cline { 2 - 4 } & $b$ & $S E b$ & $\beta$ \\
\hline $\mathrm{AT}_{\mathrm{s}}$ & 0.561 & 0.030 & $0.513^{* * *}$ \\
$\mathrm{SN}_{\mathrm{s}}$ & 0.075 & 0.022 & $0.093 * *$ \\
$\mathrm{PBC}_{\mathrm{s}}$ & 0.097 & 0.023 & $0.117^{* * *}$ \\
$\mathrm{HE}$ & 0.401 & 0.045 & $0.214 * * *$ \\
$R^{2}\left(\operatorname{adj} R^{2}\right)=.457(.455) ; F(4,961)=202.49, p<.001$ & \\
\hline
\end{tabular}

$b$ regression coefficient, $S E b$ standard error of regression coefficient, $\beta$ standardized regression coefficient, $R^{2}$ coefficient of determination, adj $R^{2}$ adjusted coefficient of determination, $F$ partial $F$ value

$* p<.05, * * p<.01, * * * p<.001$ significance codes needed in light of constantly increasing numbers and diversity of new forest owners (Feil et al. 2018; Weiss et al. 2019). It may be a question of understanding goal perception and adequate framing when the majority forest owners prioritize nature conservation measures over forestry activities, possibly because they perceive these measures as having been neglected in the past (Feil et al. 2018).

\subsection{Is there a gap in climate change awareness?}

Based on the results of the regression analysis, the cognitive dimension of awareness (AT) is most important in all ownership types for predicting intentions. Since forest management relies on well-considered action, this may not be surprising. However, in general, all dimensions of awareness as well as past experience influenced intention to some degree. Interestingly, there are clear differences between ownership types in terms of the significance of other values of the model.

The (perceived) actions of others ( $\mathrm{SN}$ ) are significantly more influential for participants representing state forests and, to a lesser degree, corporate forests. Those participants predominantly represent professional forest managers who can be seen as a community influencing each other based on a shared "standard" defining which decisions are legitimate and which are not (Detten and Hanewinkel 2017).

The question of self-efficacy (PBC) has been shown to be influential in small- and large-scale privately owned forests, whereas for participants representing large properties only measures on stand level were significantly influenced by this factor. This may be due to specific dependencies. Small-scale private forest entities are much more dependent on both their social and natural environment compared to all other groups. Since autonomy is of great importance for private forest owners (Herzele and Aarts 2013), low self-efficacy may also impact intention 
Table 8 Results of multiple regression analyses for the five forest ownership types small-scale privately owned forests (SPF) $(<20 \mathrm{ha})$, medium-scale privately owned forests (MPF) (20-100 ha), large-scale privately owned forests (LPF) (> $100 \mathrm{ha}$ ), corporate forests (CF), and state forests (SF). Displayed are the intention to apply adaptive measures on stand level $\left(\mathrm{IT}_{\mathrm{s}}\right)$ as the dependent variable and attitude $\left(\mathrm{AT}_{\mathrm{s}}\right)$, social norm $\left(\mathrm{SN}_{\mathrm{s}}\right)$, and perceived behavioral control $\left(\mathrm{PBC}_{\mathrm{s}}\right)$ regarding these measures as well as hazard experience (HE) as independent variables

\begin{tabular}{|c|c|c|c|c|c|}
\hline & $\beta \mathrm{SPF}$ & $\beta \mathrm{MPF}$ & $\beta \mathrm{LPF}$ & $\beta \mathrm{CF}$ & $\beta \mathrm{SF}$ \\
\hline $\mathrm{AT}_{\mathrm{s}}$ & $0.570 * * *$ & $0.427 * *$ & $0.574 * * *$ & $0.485 * * *$ & $0.338 * *$ \\
\hline $\mathrm{SN}_{\mathrm{s}}$ & 0.063 & 0.109 & 0.057 & $0.151^{*}$ & $0.311 * *$ \\
\hline $\mathrm{PBC}_{\mathrm{s}}$ & $0.085^{*}$ & 0.016 & $0.234 * *$ & 0.089 & 0.178 \\
\hline \multirow[t]{2}{*}{$\mathrm{HE}$} & $0.211 * * *$ & 0.150 & 0.125 & $0.141 * *$ & 0.144 \\
\hline & $\begin{array}{l}R^{2}\left(\operatorname{adj} R^{2}\right)=.481(.477) \\
F(4,471)=109.15 \\
\quad p<.001\end{array}$ & $\begin{array}{l}R^{2}\left(\operatorname{adj} R^{2}\right)=.270(.225) \\
\quad F(4,65)=5.99, p<.001\end{array}$ & $\begin{array}{l}R^{2}\left(\operatorname{adj} R^{2}\right)=.516(.494) \\
\quad F(4,88)=23.44 \\
\quad p<.001\end{array}$ & $\begin{array}{l}R^{2}\left(\operatorname{adj} R^{2}\right)=.423(.413) \\
\quad F(4,233)=42.69 \\
\quad p<.001\end{array}$ & $\begin{array}{l}R^{2}\left(\operatorname{adj} R^{2}\right)=.477(.451) \\
\quad F(4,82)=18.67, \\
\quad p<.001\end{array}$ \\
\hline
\end{tabular}

$b$ regression coefficient, $S E b$ standard error of regression coefficient, $\beta$ standardized regression coefficient, $R^{2}$ coefficient of determination, adj $R^{2}$ adjusted coefficient of determination, $F$ partial $F$ value

$* p<.05, * * p<.01, * * * p<.001$ significance codes

negatively since implementing certain measures would reinforce these actors' dependence on others such as state consultancy. Moreover, according to Wendisch (2004), self-efficacy is of particular importance in decision making under uncertainty.

Prior HE played a major role, especially for participants representing small-scale forest properties and corporate forests. This could be due to the influence of laymen in those property types. Hence, adaptive measures need to be coordinated with these actors. This could lead to a more reactive management as compared to others.

Overall, the results point to the necessity to address different aspects of awareness dependent on ownership type or position in the organization. Particularly noticeable were the lower levels of perceived adaptive measures implemented by others. Since group dynamics can play a major role in forest management (Lidskog and Sjödin 2016) and social learning is

Table 9 Results of multiple regression analysis with the intention to apply adaptive measures on business level $\left(\mathrm{IT}_{\mathrm{b}}\right)$ as the dependent variable and attitude $\left(\mathrm{AT}_{\mathrm{b}}\right)$, social norm $\left(\mathrm{SN}_{\mathrm{b}}\right)$, and perceived behavioral control $\left(\mathrm{PBC}_{\mathrm{b}}\right)$ regarding these measures as well as hazard experience $(\mathrm{HE})$ as independent variables

\begin{tabular}{llll}
\hline Scales & \multicolumn{3}{l}{$\mathrm{IT}_{\mathrm{b}}$} \\
\cline { 2 - 4 } & $b$ & $\mathrm{SE} b$ & $\beta$ \\
\hline $\mathrm{AT}_{\mathrm{b}}$ & 0.529 & 0.030 & $0.491 * * *$ \\
$\mathrm{SN}_{\mathrm{b}}$ & 0.121 & 0.028 & $0.120^{* * *}$ \\
$\mathrm{PBC}_{\mathrm{b}}$ & 0.131 & 0.026 & $0.143 * * *$ \\
$\mathrm{HE}$ & 0.493 & 0.053 & $0.214 * * *$ \\
$R^{2}\left(\operatorname{adj} R^{2}\right)=.515(.513) ; F(4,954)=253.55, p<.001$ & \\
\hline
\end{tabular}

$b$ regression coefficient, $S E b$ standard error of regression coefficient, $\beta$ standardized regression coefficient, $R^{2}$ coefficient of determination, adj $R^{2}$ adjusted coefficient of determination, $F$ partial $\mathrm{F}$ value

$* p<.05, * * p<.01, * * * p<.001$ significance codes considered an important aspect for behavior adaptation in forestry and elsewhere (Benson et al. 2016; Sample et al. 2014), this aspect cannot be underestimated. There are several initiatives based on the idea of social learning for better climate change adaptation in forests (Halofsky et al. 2018). Selfefficacy would also benefit from joint adaptation and risk management initiatives since these create a forum where future options are discussed. This, in turn, can have a positive impact on the willingness to take action (Johnson et al. 2016).

\subsection{Reflection on the study design}

Since the sample of participants was predominantly influenced by the cooperation of the administration of the federal state of Baden-Württemberg, the representativeness of the results is limited. Online surveys also tend to bias towards younger, male, and educated individuals (Jackob et al. 2008). This aspect cannot be properly evaluated due to the blind sampling via mailing lists and the snowball effect. Yet, they are in line with the findings of other studies as shown above. The theory of planned behavior proved to be suitable in the context of this study, both at the level of predicting intention and for identifying differences in climate change awareness. The latter is a new field for applying the concept by linking it to different dimensions of awareness. Clear differences between ownership types could be identified based on the model and the results fitted well into the different dimensions of awareness. In this regard, the theory of planned behavior could be further used to evaluate awareness-raising measures targeting their three dimensions.

However, there are restrictions to be addressed. The set of adaptive measures used in the study is obviously not exhaustive and not all are exclusively linked to climate change adaptation. Some of the measures are reasonable also in a broader context as they also promote other management goals. Furthermore, 
Table 10 Results of multiple regression analyses for the five forest ownership types small-scale privately owned forests (SPF) $(<20 \mathrm{ha})$, medium-scale privately owned forests (MPF) (20-100 ha), large-scale privately owned forests (LPF) (> $100 \mathrm{ha}$ ), corporate forests (CF), and state forests (SF). Displayed are the intention to apply adaptive measures on business level ( $\left.\mathrm{IT}_{\mathrm{b}}\right)$ as the dependent variable and attitude $\left(\mathrm{AT}_{\mathrm{b}}\right)$, social norm $\left(\mathrm{SN}_{\mathrm{b}}\right)$, and perceived behavioral control $\left(\mathrm{PBC}_{\mathrm{b}}\right)$ regarding these measures as well as hazard experience (HE) as independent variables

\begin{tabular}{|c|c|c|c|c|c|}
\hline & \multicolumn{5}{|l|}{$\mathrm{IT}_{\mathrm{b}}$} \\
\hline & $\beta \mathrm{SPF}$ & $\beta \mathrm{MPF}$ & $\beta \mathrm{LPF}$ & $\beta \mathrm{CF}$ & $\beta \mathrm{SF}$ \\
\hline $\mathrm{AT}_{\mathrm{b}}$ & $0.468 * * *$ & $0.581 * * *$ & $0.749 * * *$ & $0.516 * * *$ & $0.424 * * *$ \\
\hline $\mathrm{SN}_{\mathrm{b}}$ & $0.122 * *$ & 0.095 & -0.010 & $0.164 * *$ & $0.346 * * *$ \\
\hline $\mathrm{PBC}_{\mathrm{b}}$ & $0.105^{*}$ & 0.132 & 0.082 & 0.090 & 0.166 \\
\hline \multirow[t]{2}{*}{ HE } & $0.227 * * *$ & 0.014 & -0.043 & $0.159 * *$ & $0.156^{*}$ \\
\hline & $\begin{array}{l}R^{2}\left(\operatorname{adj} R^{2}\right)=.426(.421) \\
F(4,469)=86.88 \\
\quad p<.001\end{array}$ & $\begin{array}{l}R^{2}\left(\operatorname{adj} R^{2}\right)=.526(.496) \\
\quad F(4,63)=17.49 \\
\quad p<.001\end{array}$ & $\begin{array}{l}R^{2}\left(\operatorname{adj} R^{2}\right)=.631(.614) \\
\quad F(4,87)=37.15 \\
\quad p<.001\end{array}$ & $\begin{array}{l}R^{2}\left(\operatorname{adj} R^{2}\right)=.480(.471) \\
\quad F(4,232)=53.44 \\
\quad p<.001\end{array}$ & $\begin{array}{l}R^{2}\left(\operatorname{adj} R^{2}\right)=.603(.584) \\
\quad F(4,81)=30.81 \\
\quad p<.001\end{array}$ \\
\hline
\end{tabular}

$b$ regression coefficient, $S E b$ standard error of regression coefficient, $\beta$ standardized regression coefficient, $R^{2}$ coefficient of determination, adj $R^{2}$ adjusted coefficient of determination, $F$ partial $F$ value

$* p<.05, * * p<.01, * * * p<.001$ significance codes

some measures are suitable for all ownership types and property sizes, while others are less suitable in all cases. In addition, measures applied on business level have the disadvantage that their implementation cannot be observed in the same way that those on stand level can be. This may explain why values for social norm were the lowest for these measures. On the other hand, their invisibility in neighboring forest businesses may further manifest in the similarly low values for intention.

\section{Conclusion}

Tackling climate change is accepted as an important task in forest management among forest owners and managers. An important driver seems to be their own experience with hazards. The effect of "seeing is believing" (Weber 2016, p. 126) is confirmed by the study. This may also be true for the implementation of adaptive measures. Those on stand level, with a direct and visible effect on the forest, are far more frequently implemented, accepted, and considered feasible than those on the business level of forest management. The latter are not easy to implement in all ownership types and property sizes; however, it became obvious that the potential of adaptive measures is not fully exploited by focusing on the stand level. Considering awareness beyond just a linear understanding (cf. Hulme 2018) as part from knowledge leading to action, it is possible to come closer to an answer why adaptive action is still missing. All three dimensions of awareness have been shown to be important for the intention to adapt to climate change. The cognitive dimension is most important, but the affective and conative dimensions have been shown to be of high importance to some groups. According to the target group, these findings can be applied in awareness-raising initiatives and forest consultancy in order to enhance the likelihood of behavioral change.
Further research, especially investigating potential methods for forestry-related knowledge transfer, could make use of this study's findings to develop target group specific frameworks. With regard to the implementation of adaptive measures above the stand level, further research could help to develop applicable approaches to these kinds of measures for all ownership types.

Acknowledgments The author wishes to thank all participants of the survey for their valuable input.

Author contribution The author planned and conducted the survey, processed and analyzed the data, and wrote the manuscript.

Data availability The datasets generated and/or analyzed during the current study are available in the Open Science Framework repository (Hengst-Ehrhart 2019) at https://doi.org/10.17605/OSF.IO/6ER3D.

\section{Compliance with ethical standards}

Statement on ethical approval All potential participants were informed about the content and purpose of the study at the front page of the online survey. Further, a disclaimer was shown that all answers were voluntary and processed anonymously. Participants were informed that they give their informed consent by proceeding with the survey and providing the information. No personal information was collected except region, age, gender, education, profession resp. position in a forest enterprise, type, and size of the enterprise.

\section{Annex}

The full questionnaire of the study is shown in Table 11. Detailed descriptive statistics of adaptive measures on stand level are provided in Table 12, and detailed descriptive statistics of adaptive measures on business level are listed in Table 13. 
Table 11 Questions and response options of the questionnaire used in the online survey with German forest owners and managers

Questions
Q01: Do you think climate change will have an
influence on your forest?
Q02: When do you think climate change impacts
will be noticeable in your forest?

Q03: Have you experienced the following hazards? [Note: Variable "hazard experience" (HE)]

(1) Storm damage

(2) Forest fire

(3) Ice damage

(4) Flood

(5) Landslide/flash flood

(6) Drought

(7) Large-scale damages through game to the stand or regeneration

(8) Large-scale damages through insects (e.g., bark beetle)

(9) Large-scale damages through pathogens (e.g., ash dieback)

Q04: How do you assess the future damage risk of the following hazards?

(1) Storm damage

(2) Forest fire

(3) Ice damage

(4) Flood

(5) Landslide / flash flood

(6) Drought

(7) Large-scale damages through game to the stand or regeneration

(8) Large-scale damages through insects (e.g., bark beetle)

(9) Large-scale damages through pathogens (e.g., ash dieback)

How do you assess the following statements?

Q05: I consider climate change adaptation to be an important objective in my forest. [Note: Variable "behavioral belief $\left.1 "\left(\mathrm{BB}_{1}\right)\right]$

Q06: Climate change adaptation is a top priority for me. [Note: Variable "behavioral belief 2 " $\left.\left(\mathrm{BB}_{2}\right)\right]$

Q07: Climate change adaptation is an important topic in my professional environment. [Note: Variable "normative belief 1 " $\left.\left(\mathrm{NB}_{1}\right)\right]$

Q08: I consider the adaptation of forests to climate change an important social task. [Note: Variable "normative belief 2 " $\left.\left(\mathrm{NB}_{1}\right)\right]$

Q09: The present state of science is sufficient for a successful climate change adaptation of my forest business. [Note: "Variable control belief $\left.1 "\left(\mathrm{CB}_{1}\right)\right]$

Q10: As forest owners or managers it is in our hands to successfully adapt our forests to climate change. [Note: Variable "control belief $\left.2 "\left(\mathrm{CB}_{2}\right)\right]$
Response options
Justification

\section{No influence to strong influence (7-point Likert scale)}

Not at all (0), right now (1), in the next 10 years (2), in the next 20 years (3), in the next 50 years (4), in the next 100 years (5), later (6)

Not yet (0), once (1), seldom (2), frequent (3)

Significantly lower $(-3)$, lower $(-2)$, slightly lower $(-1)$, constant $(0)$, slightly higher (1), higher (2), significantly higher (3)
I do not agree to I fully agree (7-point Likert scale) 7-point Likert scale used for comparison reasons with the variables of the theory of planned behavior

Typical future projections cover 100 years; as such, response options were distributed across this time frame

4-point semantic differential scale used to cover subjective experience of hazards. Since these values cannot be quantified among several respondents, a low number of response options was chosen to increase comparability. 7-point Likert scale used for comparison reasons with the variables of the theory of planned behavior 7-point Likert scale is established in the application of the theory of planned behavior (Ajzen 2002)

7-point Likert scale is established in the application of the theory of planned behavior (Ajzen 2002)

7-point Likert scale is established in the application of the theory of planned behavior (Ajzen 2002)

7-point Likert scale is established in the application of the theory of planned behavior (Ajzen 2002)

7-point Likert scale is established in the application of the theory of planned behavior (Ajzen 2002)

7-point Likert scale is established in the application of the theory of planned behavior (Ajzen 2002) 
Table 11 (continued)

Questions

Q11: Which of these adaptive measures have you already implemented?

(1) Enrichment with further tree species (mixed forests or on property level)

(2) Cultivation of drought-resistant tree species

(3) Thinning to stabilize forest stands

(4) Frequent patrols to ensure recognition of potential damages

(5) Shorter rotation periods to secure stand stability

(6) Sufficient road networks to ensure the accessibility of (potentially) damaged areas

(7) Insurance or financial reserves in case of damages (e.g., storm, fire)

(8) Consideration of individual risk factors in operational planning

(9) Adaptation of operational goals to new climatic conditions

(10) Cooperation and agreements with other forest owners in cases of damage

Q12: How likely is it that you will (further) implement the following adaptive measures in the next ten years? [Note: Variable "intention" (IT)]

(1) Enrichment with further tree species (mixed forests or on property level)

(2) Cultivation of drought-resistant tree species

(3) Thinning to stabilize forest stands

(4) Frequent patrols to ensure recognition of potential damages

(5) Shorter rotation periods to secure stand stability

(6) Sufficient road networks to ensure the accessibility of (potentially) damaged areas

(7) Insurance or financial reserves in case of damages (e.g., storm, fire)

(8) Consideration of individual risk factors in operational planning

(9) Adaptation of operational goals to new climatic conditions

(10) Cooperation and agreements with other forest owners in cases of damage

Q13: How do you assess the following measures for climate change adaptation? [Note: Variable "attitude" (AT)]

(1) Enrichment with further tree species (mixed forests or on property level)

(2) Cultivation of drought-resistant tree species

(3) Thinning to stabilize forest stands

(4) Frequent patrols to ensure recognition of potential damages

(5) Shorter rotation periods to secure stand stability

(6) Sufficient road networks to ensure the accessibility of (potentially) damaged areas

(7) Insurance or financial reserves in case of damages (e.g., storm, fire)
Response options

Justification

Dichotomous variable

Not implemented (0), implemented (1)

Unlikely to likely (7-point Likert scale)

Unsuitable for climate change adaption to suitable for climate change adaptation (7-point Likert scale) 7-point Likert scale is established in the application of the theory of planned behavior (Ajzen 2002)

7-point Likert scale is established in the application of the theory of planned behavior (Ajzen 2002) 
Table 11 (continued)

(8) Consideration of individual risk factors in operational planning

(9) Adaptation of operational goals to new climatic conditions

(10) Cooperation and agreements with other forest owners in cases of damage

Q14: The following adaptive measures are endorsed and implemented in my professional environment (e.g., by neighboring forest owners, forest owner associations, consultants).

[Note: Variable "social norm" (SN)]

(1) Enrichment with further tree species (mixed forests or on property level)

(2) Cultivation of drought-resistant tree species

(3) Thinning to stabilize forest stands

(4) Frequent patrols to ensure recognition of potential damages

(5) Shorter rotation periods to secure stand stability

(6) Sufficient road networks to ensure the accessibility of (potentially) damaged areas

(7) Insurance or financial reserves in case of damages (e.g., storm, fire)

(8) Consideration of individual risk factors in operational planning

(9) Adaptation of operational goals to new climatic conditions

(10) Cooperation and agreements with other forest owners in cases of damage

Q15: I (or my consultants) have the necessary knowledge and resources to implement the following adaptive measures. [Note: Variable "perceived behavioral control" (PBC)]

(1) Enrichment with further tree species (mixed forests or on property level)

(2) Cultivation of drought-resistant tree species

(3) Thinning to stabilize forest stands

(4) Frequent patrols to ensure recognition of potential damages

(5) Shorter rotation periods to secure stand stability

(6) Sufficient road networks to ensure the accessibility of (potentially) damaged areas

(7) Insurance or financial reserves in case of damages (e.g., storm, fire)

(8) Consideration of individual risk factors in operational planning

(9) Adaptation of operational goals to new climatic conditions

(10) Cooperation and agreements with other forest owners in cases of damage

Q16: Which ownership type can your forest be attributed to?

Q17: What is the size of your forest?

Private forest, corporate forest, state forest $<2$ ha, $<5$ ha, $<20$ ha, $<50$ ha, $<100$ ha,
$<200$ ha, $>200$ ha

Q18: Which function do you have? [Note: multiple answers possible]

Owner, operation manager, forest ranger, consultant, other (free input)
I do not agree to I fully agree (7-point Likert scale)

I do not agree to I fully agree (7-point Likert scale) 7-point Likert scale is established in the application of the theory of planned behavior (Ajzen 2002)

7-point Likert scale is established in the application of the theory of planned behavior (Ajzen 2002)

Ownership types in Germany

Typical categorization of property sizes in Germany

Typical possible categories in forest enterprises in Germany 
Table 11 (continued)

\begin{tabular}{|c|c|c|}
\hline Questions & Response options & Justification \\
\hline Q19: Do you have a forestry education? & $\begin{array}{l}\text { No forestry related education, vocational } \\
\text { training, academic education }\end{array}$ & Typical qualification pathways in Germany \\
\hline $\begin{array}{l}\text { Q20: Is your forest business part of a management } \\
\text { cooperative? }\end{array}$ & Yes, no & $\begin{array}{l}\text { Degree of organization, typically in small-scale } \\
\text { private forests }\end{array}$ \\
\hline Q21: Please enter you age. & Free input & \\
\hline Q22: Please select your gender. & Male, female, other/no response & \\
\hline Q23: Please name your region. & Choice of all German federal states & \\
\hline
\end{tabular}

Table 12 Detailed descriptive statistics of adaptive measures on stand level. Displayed are percentages of past implementation (PI) as well as mean scores $(M)$ and standard deviations $(S D)$ of intention to implement these (IT), and attitude (AT), social norm (SN), and perceived behavioral control (PBC) towards them. Listed are values of small-scale private forests (SPF), medium-scale private forests, large-scale private forests (LPF), corporate forests $(\mathrm{CF})$, and state forests $(\mathrm{SF})$

\begin{tabular}{|c|c|c|c|c|c|c|c|c|c|}
\hline & PI & $\begin{array}{l}\text { IT } \\
M\end{array}$ & $S D$ & $\begin{array}{l}\mathrm{AT} \\
M\end{array}$ & $S D$ & $\begin{array}{l}\mathrm{SN} \\
M\end{array}$ & $S D$ & $\begin{array}{l}\text { PBC } \\
M\end{array}$ & $S D$ \\
\hline \multicolumn{10}{|c|}{ (1) Enrichment with further tree species (mixed forests or on property level) } \\
\hline SPF & $82.6 \%$ & 1.69 & 1.43 & 2.01 & 1.29 & 0.90 & 1.71 & 0.95 & 1.66 \\
\hline MPF & $82.6 \%$ & 1.82 & 1.35 & 1.92 & 1.37 & 1.11 & 1.57 & 1.25 & 1.54 \\
\hline LPF & $90.3 \%$ & 2.02 & 1.42 & 2.11 & 1.26 & 1.18 & 1.52 & 1.72 & 1.37 \\
\hline $\mathrm{CF}$ & $92.5 \%$ & 2.05 & 1.28 & 2.16 & 1.12 & 1.35 & 1.49 & 1.52 & 1.41 \\
\hline SF & $93.1 \%$ & 2.01 & 1.30 & 2.26 & 0.96 & 1.37 & 1.57 & 1.61 & 1.32 \\
\hline Total & & 1.85 & 1.39 & 2.07 & 1.23 & 1.09 & 1.63 & 1.25 & 1.57 \\
\hline \multicolumn{10}{|c|}{ (2) Cultivation of drought-resistant tree species } \\
\hline SPF & $43.7 \%$ & 1.12 & 1.72 & 1.76 & 1.36 & 0.50 & 1.80 & 0.43 & 1.81 \\
\hline MPF & $61.1 \%$ & 1.41 & 1.78 & 2.04 & 1.35 & 0.87 & 1.75 & 1.18 & 1.55 \\
\hline LPF & $72.0 \%$ & 1.75 & 1.46 & 2.01 & 1.13 & 0.80 & 1.61 & 1.16 & 1.58 \\
\hline $\mathrm{CF}$ & $80.4 \%$ & 1.93 & 1.18 & 2.20 & 1.00 & 1.18 & 1.49 & 1.05 & 1.63 \\
\hline SF & $74.7 \%$ & 1.71 & 1.42 & 2.15 & 1.02 & 0.92 & 1.71 & 0.98 & 1.46 \\
\hline Total & & 1.46 & 1.59 & 1.95 & 1.24 & 0.76 & 1.72 & 0.76 & 1.72 \\
\hline \multicolumn{10}{|c|}{ (3) Thinnings to stabilize forest stands } \\
\hline SPF & $78.5 \%$ & 1.28 & 1.52 & 1.23 & 1.52 & 0.60 & 1.65 & 0.98 & 1.65 \\
\hline MPF & $79.2 \%$ & 1.56 & 1.46 & 1.40 & 1.46 & 0.82 & 1.48 & 1.25 & 1.57 \\
\hline LPF & $82.8 \%$ & 1.78 & 1.57 & 1.19 & 1.75 & 0.61 & 1.62 & 1.84 & 1.45 \\
\hline $\mathrm{CF}$ & $87.1 \%$ & 1.73 & 1.47 & 1.27 & 1.47 & 0.95 & 1.57 & 1.90 & 1.41 \\
\hline $\mathrm{SF}$ & $86.2 \%$ & 1.82 & 1.58 & 0.98 & 1.73 & 0.80 & 1.77 & 1.79 & 1.46 \\
\hline Total & & 1.51 & 1.53 & 1.23 & 1.55 & 0.72 & 1.63 & 1.38 & 1.61 \\
\hline \multicolumn{10}{|c|}{ (4) Frequent patrols to ensure recognition of potential damages } \\
\hline SPF & $87.9 \%$ & 1.93 & 1.39 & 1.86 & 1.40 & 0.92 & 1.73 & 1.52 & 1.57 \\
\hline MPF & $86.1 \%$ & 2.10 & 1.27 & 1.99 & 1.44 & 1.20 & 1.51 & 1.76 & 1.36 \\
\hline LPF & $86.0 \%$ & 1.99 & 1.44 & 1.74 & 1.51 & 0.87 & 1.72 & 1.68 & 1.45 \\
\hline $\mathrm{CF}$ & $82.5 \%$ & 1.81 & 1.44 & 1.47 & 1.58 & 1.14 & 1.59 & 1.55 & 1.49 \\
\hline SF & $88.5 \%$ & 2.01 & 1.51 & 1.37 & 1.82 & 0.98 & 1.82 & 1.31 & 1.70 \\
\hline Total & & 1.93 & 1.41 & 1.71 & 1.51 & 1.00 & 1.69 & 1.54 & 1.54 \\
\hline
\end{tabular}

Theoretical range of IT, AT, SN, and $\mathrm{PBC}=-3-3$ 
Table 13 Detailed descriptive statistics of adaptive measures on business level. Displayed are percentages of past implementation (PI) as well as mean scores $(M)$ and standard deviations $(S D)$ of intention to implement these (IT), and attitude (AT), social norm (SN) and perceived behavioral control (PBC) towards them. Listed are values of small-scale private forests $(\mathrm{SPF})$, medium-scale private forests, large-scale private forests $(\mathrm{LPF})$, corporate forests $(\mathrm{CF})$, and state forests $(\mathrm{SF})$

$\begin{array}{lll}\text { PI } & \text { IT } & \\ & M & S D\end{array}$

$\begin{array}{ll}\text { AT } & \\ M & S D\end{array}$

$\mathrm{SN}$

$-0.60$

$-0.37$

$-0.05$

$-0.08$

$-0.42$

$-0.39$
1.97

1.91

$-0.36$

1.88

(2) Sufficient road networks to ensure the accessibility of (potentially) damaged areas

$\begin{array}{llllll}\text { SPF } & 34.1 \% & -0.15 & 1.98 & 0.54 & 1.80 \\ \text { MPF } & 58.3 \% & 0.49 & 2.08 & 1.09 & 1.74 \\ \text { LPF } & 74.2 \% & 0.91 & 2.15 & 1.14 & 1.73 \\ \text { CF } & 59.2 \% & 0.68 & 1.85 & 0.79 & 1.68 \\ \text { SF } & 59.8 \% & 0.83 & 2.02 & 0.90 & 1.87 \\ \text { Total } & & 0.29 & 2.02 & 0.73 & 1.78\end{array}$

(3) Insurance or financial reserves in case of damages (e.g., storm, fire)

$\begin{array}{lllll}\text { SPF } & 6.1 \% & -2.01 & 1.55 & -1.34 \\ \text { MPF } & 13.9 \% & -1.39 & 1.96 & -0.67 \\ \text { LPF } & 24.7 \% & -0.89 & 2.04 & -0.53 \\ \text { CF } & 13.8 \% & -1.50 & 1.78 & -1.03 \\ \text { SF } & 0.0 \% & -2.09 & 1.35 & -1.23 \\ \text { Total } & & -1.74 & 1.71 & -1.13\end{array}$

(4) Consideration of individual risk factors in operational planning

$\begin{array}{lllll}\text { SPF } & 13.6 \% & -0.86 & 1.94 & -0.22 \\ \text { MPF } & 20.8 \% & -0.15 & 2.01 & 0.21 \\ \text { LPF } & 37.6 \% & 0.65 & 1.97 & 0.58 \\ \text { CF } & 49.6 \% & 0.90 & 1.70 & 0.97 \\ \text { SF } & 37.9 \% & 0.43 & 1.97 & 1.07 \\ \text { Total } & & -0.11 & 2.05 & 0.30\end{array}$

(5) Adaption of operational goals to new climatic conditions

\begin{tabular}{|c|c|c|c|c|c|c|c|c|c|}
\hline SPF & $27.8 \%$ & 0.29 & 1.99 & 0.91 & 1.77 & -0.12 & 1.82 & -0.07 & 1.85 \\
\hline MPF & $36.1 \%$ & 0.97 & 1.69 & 1.31 & 1.52 & 0.23 & 1.81 & 0.31 & 1.79 \\
\hline LPF & $61.3 \%$ & 1.22 & 1.65 & 1.15 & 1.77 & -0.10 & 1.87 & 0.77 & 1.88 \\
\hline $\mathrm{CF}$ & $51.7 \%$ & 1.39 & 1.45 & 1.55 & 1.40 & 0.44 & 1.73 & 0.80 & 1.68 \\
\hline SF & $47.1 \%$ & 1.01 & 1.87 & 1.79 & 1.55 & -0.02 & 1.75 & 0.55 & 1.72 \\
\hline Total & & 0.77 & 1.87 & 1.20 & 1.68 & 0.06 & 1.81 & 0.31 & 1.84 \\
\hline \multicolumn{10}{|c|}{ (6) Cooperation and agreements with other forest owners in cases of damage } \\
\hline SPF & $37.0 \%$ & 0.07 & 2.15 & 0.42 & 1.98 & -0.28 & 1.92 & -0.18 & 1.99 \\
\hline MPF & $37.5 \%$ & 0.33 & 2.08 & 0.47 & 1.98 & 0.21 & 2.04 & 0.09 & 2.04 \\
\hline LPF & $33.3 \%$ & 0.39 & 2.10 & 0.36 & 1.86 & -0.42 & 1.85 & 0.23 & 2.04 \\
\hline $\mathrm{CF}$ & $32.5 \%$ & 0.26 & 2.00 & 0.19 & 1.90 & -0.31 & 1.84 & 0.16 & 2.05 \\
\hline SF & $34.5 \%$ & -0.08 & 2.01 & 0.28 & 2.00 & -0.77 & 1.84 & -0.10 & 1.95 \\
\hline Total & & 0.15 & 2.09 & 0.35 & 1.95 & -0.31 & 1.90 & -0.03 & 2.01 \\
\hline
\end{tabular}

Theoretical range of IT, AT, $\mathrm{SN}$, and $\mathrm{PBC}=-3-3$

74

1.73

1.68

1.87

1.78

1.80

1.98

1.99

1.85

1.85

1.86

1.84

1.84

2.03

1.60

1.57

1.86

0.05

0.51

0.15

0.29

0.24

0.17

$-1.64$

$-1.31$

$-1.35$

$-1.65$

$-2.12$

$-1.63$

$-0.79$

$-0.45$

$-0.23$

0.11

$-0.01$

$-0.42$

1.77

1.73

1.79

1.74

1.97

1.78

PBC

M

$S D$

$\begin{array}{lll}1.60 & -1.62 & 1.72 \\ 1.55 & -1.09 & 1.95 \\ 1.69 & -0.49 & 2.13 \\ 1.56 & -0.84 & 2.02 \\ 1.30 & -1.62 & 1.89 \\ 1.58 & -1.28 & 1.91\end{array}$

1.75

$-0.84$

1.80

1.69

$-0.14$

1.78

0.51

2.04

1.70

0.74

1.74

1.77

0.61

1.69

1.79

$-0.13$

1.94

.85

1.79

88

.72

.84

.99

04

.05

95

2.01 


\section{References}

Ajzen I (1991) The theory of planned behavior. Organ Behav Hum Decis Process 50:179-211. https://doi.org/10.1016/0749-5978(91)90020-T

Ajzen I (2002) Constructing a theory of planned behavior questionnaire. http://people.umass.edu/ aizen/pdf/tpb.measurement.pdf. Accessed 15 July 2018

Ajzen I (2015) Consumer attitudes and behavior: the theory of planned behavior applied to food consumption decisions. Riv Econ Agrar 70:121-138. https://doi.org/10.13128/REA-18003

Ajzen I, Cote NG (2008) Attitudes and the prediction of behavior. In: Prislin R, Crano WD (eds) Attitudes and attitude change. Psychology Press, New York, London, pp 289-311

Ajzen I, Joyce N, Sheikh S, Cote NG (2011) Knowledge and the prediction of behavior: the role of information accuracy in the theory of planned behavior. Basic Appl Soc Psychol 33:101-117. https://doi. org/10.1080/01973533.2011.568834

Aldunce P, Handmer J, Beilin R, Howden M (2016) Is climate change framed as 'business as usual' or as a challenging issue?: the practitioners' dilemma. Eviron Plann C Gov Policy 34:999-1019. https:// doi.org/10.1177/0263774X15614734

Baasch S, Bauriedl S, Hafner S, Weidlich S (2012) Klimaanpassung auf regionaler Ebene: Herausforderungen einer regionalen Klimawandel-Governance. Raumforsch Raumordn 70:191-201. https://doi.org/10.1007/s13147-012-0155-1

Bandura A (1977) Self-efficacy: toward a unifying theory of behavioral change. Psychol Rev 84:191-215. https://doi.org/10.1037/0033295X.84.2.191

Benson D, Lorenzoni I, Cook H (2016) Evaluating social learning in England flood risk management: an 'individual-community interaction' perspective. Environ Sci Pol 55:326-334. https://doi.org/10. 1016/j.envsci.2015.05.013

Blennow K (2012) Adaptation of forest management to climate change among private individual forest owners in Sweden. Forest Policy Econ 24:41-47. https://doi.org/10.1016/j.forpol.2011.04.005

Blennow K, Persson J (2009) Climate change: motivation for taking measure to adapt. Glob Environ Chang 19:100-104. https://doi. org/10.1016/j.gloenvcha.2008.10.003

Blennow K, Persson J, Tome M, Hanewinkel M (2012) Climate change: believing and seeing implies adapting. PLoS One 7:e50182. https:// doi.org/10.1371/journal.pone.0050182

Blennow K, Persson J, Persson E, Hanewinkel M (2016) Forest owners' response to climate change: university education trumps value profile. PLoS One 11:e155137. https://doi.org/10.1371/journal.pone. 0155137

Blennow K, Persson E, Persson J (2019) Are values related to culture, identity, community cohesion and sense of place the values most vulnerable to climate change? PLoS One 14:e210426. https://doi. org/10.1371/journal.pone.0210426

Carrington MJ, Neville BA, Whitwell GJ (2010) Why ethical consumers don't walk their talk: towards a framework for understanding the gap between the ethical purchase intentions and actual buying behaviour of ethically minded consumers. J Bus Ethics 97:139-158. https://doi.org/10.1007/s10551-010-0501-6

Detten R, Faber F (2013) Organizational decision-making by German state-owned forest companies concerning climate change adaptation measures. Forest Policy Econ 35:57-65. https://doi.org/10.1016/j. forpol.2013.06.009

Detten R, Hanewinkel M (2017) Strategies of handling risk and uncertainty in forest management in Central Europe. Curr For Rep 3:60 73. https://doi.org/10.1007/s40725-017-0050-7

Dittrich R, Wreford A, Moran D (2016) A survey of decision-making approaches for climate change adaptation: are robust methods the way forward? Ecol Econ 122:79-89
Feil P, Neitzel C, Seintsch B, Dieter M (2018) Privatwaldeigentümer in Deutschland: Ergebnisse einer bundesweiten Telefonbefragung von Personen mit und ohne Waldeigentum. Appl Agric Forestry Res:87130. https://doi.org/10.3220/LBF1547703799000

Fishbein M, Ajzen I (1975) Belief, attitude, intention and behavior: an introduction to theory and research. Addison-Wesley series in social psychology. Addison-Wesley, Reading, Mass

Gigerenzer G (2008) Gut feelings: the intelligence of the unconscious. Penguin Books, London

Grothmann T, Patt A (2005) Adaptive capacity and human cognition: the process of individual adaptation to climate change. Glob Environ Chang 15:199-213. https://doi.org/10.1016/j.gloenvcha.2005.01. 002

Grotta AT, Creighton JH, Schnepf C, Kantor S (2013) Family forest owners and climate change: understanding, attitudes, and educational needs. J For 111:87-93. https://doi.org/10.5849/jof.12-052

Hair JF, Black WC, Babin BJ, Anderson RE (2014) Multivariate data analysis: Pearson New International Edition, 7. ed., new internat. ed. Pearson Education Limited

Halofsky JE, Andrews-Key SA, Edwards JE, Johnston MH, Nelson HW, Peterson DL, Schmitt KM, Swanston CW, Williamson TB (2018) Adapting forest management to climate change: the state of science and applications in Canada and the United States. For Ecol Manag 421:84-97. https://doi.org/10.1016/j.foreco.2018.02.037

Hanewinkel M, Hummel S, Albrecht A (2011) Assessing natural hazards in forestry for risk management: a review. Eur J For Res 130:329 351. https://doi.org/10.1007/s10342-010-0392-1

Hankins M, French D, Horne R (2000) Statistical guidelines for studies of the theory of reasoned action and the theory of planned behaviour. Psychol Health 15:151-161. https://doi.org/10.1080/ 08870440008400297

Hengst-Ehrhart Y (2019) Linking climate change knowledge and action. V1. OSF. [dataset]. https://doi.org/10.17605/OSF.IO/6ER3D. Accessed 15 July 2019

Herzele A, Aarts N (2013) "My forest, my kingdom" - self-referentiality as a strategy in the case of small forest owners coping with government regulations. Policy Sci 46:63-81. https://doi.org/10.1007/ s11077-012-9157-7

Hulme M (2018) "Gaps" in climate change knowledge. Environl Humanit 10:330-337. https://doi.org/10.1215/22011919-4385599

IPCC 2012 Managing the Risks of Extreme Events and Disasters to Advance Climate Change Adaptation. A Special Report of Working Groups I and II of the Intergovernmental Panel on Climate Change [Field CB, Barros V, Stocker TF, Qin D, Dokken DJ, Ebi KL, Mastrandrea MD, Mach KJ, Plattner GK, Allen SK, Tignor M, and Midgley PM (eds.)]. Cambridge University Press, Cambridge, UK, and New York, NY, USA, 582 pp.

Jackob N, Schoen H, Zerback T (2008) Online-Befragung, 1. Aufl. VS Verlag für Sozialwissenschaften, Wiesbaden

Johnson ML, Bell KP, Teisl MF (2016) Does reading scenarios of future land use changes affect willingness to participate in land use planning? Land Use Policy 57:44-52. https://doi.org/10.1016/j. landusepol.2016.05.007

Joireman J, Barnes Truelove H, Duell B (2010) Effect of outdoor temperature, heat primes and anchoring on belief in global warming. J Environ Psychol 30:358-367. https://doi.org/10.1016/j.jenvp.2010. 03.004

Kaiser FG, Hubner G, Bogner FX (2005) Contrasting the theory of planned behavior with the value-belief-norm model in explaining conservation Behavior1. J Appl Soc Pyschol 35:2150-2170. https://doi.org/10.1111/j.1559-1816.2005.tb02213.x

Krüger D, Vogt H (eds) (2007) Theorien in der biologiedidaktischen Forschung. Springer-Lehrbuch. Springer Berlin Heidelberg, Berlin, Heidelberg 
van Lange P, Kruglanski A, Higgins E (eds) (2012) Handbook of theories of social psychology: Volume 1. SAGE Publications Ltd, 1 Oliver's Yard, 55 City Road, London EC1Y 1SP United Kingdom

LaPiere RT (1934) Attitudes vs. actions. Soc Forces 13:230-237. https:// doi.org/10.2307/2570339

Lawrence J, Quade D, Becker J (2014) Integrating the effects of flood experience on risk perception with responses to changing climate risk. Nat Hazards 74:1773-1794. https://doi.org/10.1007/s11069014-1288-Z

de Leeuw A, Valois P, Ajzen I, Schmidt P (2015) Using the theory of planned behavior to identify key beliefs underlying proenvironmental behavior in high-school students: implications for educational interventions. J Environ Psychol 42:128-138. https:// doi.org/10.1016/j.jenvp.2015.03.005

Lidskog R, Sjödin D (2014) Why do forest owners fail to heed warnings?: conflicting risk evaluations made by the Swedish forest agency and forest owners. Scand J For Res:1-8. https://doi.org/10.1080/ 02827581.2014 .910268

Lidskog R, Sjödin D (2016) Risk governance through professional expertise. Forestry consultants' handling of uncertainties after a storm disaster. J Risk Res 19:1275-1290

Loewenstein GF, Weber EU, Hsee CK, Welch N (2001) Risk as feelings. Psychol Bull 127:267-286. https://doi.org/10.1037//0033-2909. 127.2.267

Morin MB, Kneeshaw D, Doyon F, Le Goff H, Bernier P, Yelle V, Blondlot A, Houle D (2015) Climate change and the forest sector: perception of principal impacts and of potential options for adaptation. For Chron 91:395-406. https://doi.org/10.5558/tfc2015-069

Oxford online dictionary (n.d.) Awareness. https://en.oxforddictionaries. com/definition/awareness . Accessed 15 Nov 2018

Pahl S, Sheppard S, Boomsma C, Groves C (2014) Perceptions of time in relation to climate change. WIREs Clim Change 5:375-388. https:// doi.org/10.1002/wcc. 272

Preisendörfer P (1999) Umwelteinstellungen und Umweltverhalten in Deutschland. VS Verlag für Sozialwissenschaften, Wiesbaden

Pröbstl-Haider U, Mostegl NM, Jandl R, Formayer H, Haider W, Pukall K, Melzer V (2017) Bereitschaft zur Klimaanpassung durch Kleinwaldbesitzer in Österreich. Allgemeine Forst- und Jagdzeitung 7/8:113-126

Roeser S (2012) Risk communication, public engagement, and climate change: a role for emotions. Risk Anal 32:1033-1040. https://doi. org/10.1111/j.1539-6924.2012.01812.x

Sample VA, Halofsky JE, Peterson DL (2014) US strategy for forest management adaptation to climate change: building a framework for decision making. Ann For Sci 71:125-130. https://doi.org/10. 1007/s13595-013-0288-6

Seidl R, Aggestam F, Rammer W, Blennow K, Wolfslehner B (2016) The sensitivity of current and future forest managers to climate-induced changes in ecological processes. Ambio 45:430-441. https://doi. org/10.1007/s13280-015-0737-6

Seidl R, Thom D, Kautz M, Martin-Benito D, Peltoniemi M, Vacchiano G, Wild J, Ascoli D, Petr M, Honkaniemi J, Lexer MJ, Trotsiuk V, Mairota P, Svoboda M, Fabrika M, Nagel TA, Reyer CPO (2017) Forest disturbances under climate change. Nat Clim Chang 7:395402. https://doi.org/10.1038/NCLIMATE3303

Slovic P, Finucane M, Peters E, MacGregor DG (2002) Rational actors or rational fools: implications of the affect heuristic for behavioral economics. J Socio-Econ 31:329-342. https://doi.org/10.1016/ S1053-5357(02)00174-9

Sousa-Silva R, Ponette Q, Verheyen K, van Herzele A, Muys B (2016) Adaptation of forest management to climate change as perceived by forest owners and managers in Belgium. For Ecosyst 3:3. https://doi. org/10.1186/s40663-016-0082-7

Sousa-Silva R, Verbist B, Lomba Â, Valent P, Suškevičs M, Picard O, Hoogstra-Klein MA, Cosofret V-C, Bouriaud L, Ponette Q, Verheyen K, Muys B (2018) Adapting forest management to climate change in Europe: linking perceptions to adaptive responses. Forest Policy Econ 90:22-30

Steinmetz H, Knappstein M, Ajzen I, Schmidt P, Kabst R (2016) How effective are behavior change interventions based on the theory of planned behavior? Z Psychol 224:216-233. https://doi.org/10.1027/ 2151-2604/a000255

Swanston C (2016) Forest adaptation resources: climate change tools and approaches for land managers. Rep. NRS-87, Newtown Square. https://doi.org/10.2737/NRS-GTR-87-2

Taddicken M, Neverla I (2011) Klimawandel aus Sicht der Mediennutzer. M\&K Medien \& Kommunikationswissenschaft 59:505-525. https://doi.org/10.5771/1615-634x-2011-4-505

Wachinger G, Renn O, Begg C, Kuhlicke C (2013) The risk perception paradox-implications for governance and communication of natural hazards. Risk Anal 33:1049-1065. https://doi.org/10.1111/j.15396924.2012.01942.x

Watkiss P, Hunt A, Blyth W, Dyszynski J (2015) The use of new economic decision support tools for adaptation assessment: a review of methods and applications, towards guidance on applicability. Clim Chang 132:401-416. https://doi.org/10.1007/s10584-014-1250-9

Weber EU (2006) Experience-based and description-based perceptions of long-term risk: why global warming does not scare us (yet). Clim Chang 77:103-120. https://doi.org/10.1007/s10584-006-9060-3

Weber EU (2016) What shapes perceptions of climate change?: new research since 2010. WIREs Clim Change 7:125-134. https://doi. org/10.1002/wcc.377

Weiss G, Lawrence A, Hujala T, Lidestav G, Nichiforel L, Nybakk E, Quiroga S, Sarvašová Z, Suarez C, Živojinović I (2019) Forest ownership changes in Europe: state of knowledge and conceptual foundations. Forest Policy Econ 99:9-20. https://doi.org/10.1016/j. forpol.2018.03.003

Wendisch N (2004) Das Leitbild und seine Rolle für das Lernen in Organisationen: Die Möglichkeit des EMAS für eine leitbildzentrierte Organisationsentwicklung, vol 1, 2nd edn. Hochschulschriften zur Nachhaltigkeit, ökom-Verl., München

Yousefpour R, Hanewinkel M (2015) Forestry professionals' perceptions of climate change, impacts and adaptation strategies for forests in south-west Germany. Clim Chang 130:273-286. https://doi.org/10. 1007/s10584-015-1330-5

Yousefpour R, Augustynczik ALD, Hanewinkel M (2017) Pertinence of reactive, active, and robust adaptation strategies in forest management under climate change. Ann For Sci 74:660. https://doi.org/10. 1007/s13595-017-0640-3

Publisher's note Springer Nature remains neutral with regard to jurisdictional claims in published maps and institutional affiliations. 